Portland State University

PDXScholar

1972

\title{
The life cycle of Lissorchis heterorchis, Macy and Krygier (1969)
}

Brendan P. H. Onyejekwe

Portland State University

Follow this and additional works at: https://pdxscholar.library.pdx.edu/open_access_etds

Part of the Microbiology Commons, Parasitology Commons, and the Zoology Commons Let us know how access to this document benefits you.

\section{Recommended Citation}

Onyejekwe, Brendan P. H., "The life cycle of Lissorchis heterorchis, Macy and Krygier (1969)" (1972). Dissertations and Theses. Paper 971.

https://doi.org/10.15760/etd.971

This Thesis is brought to you for free and open access. It has been accepted for inclusion in Dissertations and Theses by an authorized administrator of PDXScholar. Please contact us if we can make this document more accessible: pdxscholar@pdx.edu. 
AH ABRMCI OF THE PIISIS OF Brendan Onyejekwe for the Vasters of Science in Bioloy presented Hay 3, 1972.

Title: Studies on the Iife Cycle of the Trematode, Iissorchis heterorchis Wacy and Kryeier (1969).

APPROVED BY IFHERS OF THE NHESIS COMITTEE:

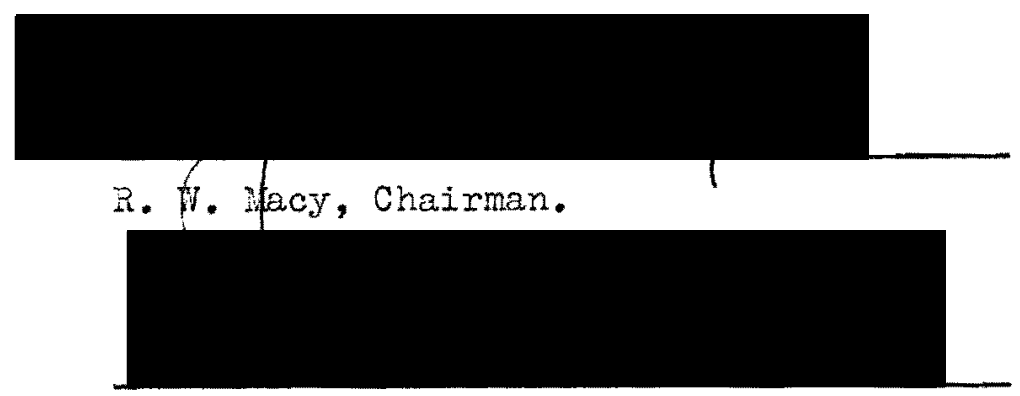

Leonard Simpson.

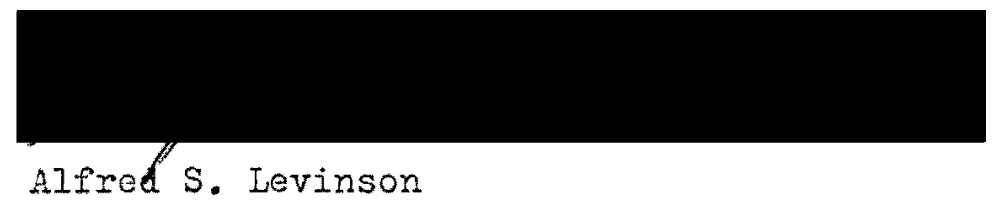

Wany Flumenicola virens (Lea) collected from Crystal Springs Creek and Tualatin River, Portland, Orezon, were found to shed large nurbers of a species of microcercous cercariae containing refractile granules. They resembled the cercariae of Triganodistomum mutabile (=Lissorchis mutabile Cort, 1918) as described by Wallace (1939), and subsequent experiments proved that they were the larval stages of what was described by Ilacy and Krygier (1969), as Lissorchis heterorchis. Encystment of these cercariae was induced experimentally in uninfected adult brown planarians collected partly from Crystal Springs creek and partly from Carolina Biological Research Station in Gladstone, Portland, Oregon. Adult flukes were obtained by feeding infected planarians to roughscaled suckers which occur in sone creeks and rivers in Oregon. In another experinent, eges recovered from adult Lissorchis heterorchis Wacy and Krygier, were experimentally fed to snails, Flumenicola virens 
(Ife). The snails after five weeks of incubation in an aquarium developed cercariee which natched both in morphology and measurements with the cerceriae from the neturally infected snails, Flumenicola virens. The exporimental cercariae were also induced to encyst in the uninfected planarians from the crystal Springs. Whese cysts matched with cysts from the first experiment with respect to the measurenents. Thus, this life cycle follows the same pattem described by Wallace (1939) in which the egrs of the adult tissorchis mutabile swallowed by the snall first intermediate host develops into rediae that gave rise to lissorchid cercariae. The cerciae produced encyst in planaria or en annelid, tentatively identified as Chaetogaster limnaei $v$ Baer the metacercariae of which when eaten by a sucker develops into adult Lissorchis mutabile.

For this life cycle under investigation, two intermediate hosts are necessary, one, a snail, and two, a planarian or an annelid. Direct infection of the definitive host with the eggs or the unencysted cercariae shows that no adults are formed. Attempted infection of the definitive host with infected planarians in which the cysts were less than five weeks old in the planaria also shows that no adults were formed. Txperiments carried out on the sheding rate of cercariae shows that the cercariae are shed in small numbers so that the productivity of concariae is low. Examination of 7200 Flumenicola shows that there is only $3 \%$ incidence in these snails and there is no marked seasonal variation in the incidence. Continuous light inhibits the rate of cercaria discharge whereas continuous darkness promotes the rate of cercaria discharge. 
THE LIFE CYCLE OF IISSORCHIS HETTRORCHIS

IHAY AND KRYGIER (1969).

\section{by}

BREMDAN P. H. ONYEJEKYIS

A thesis submitted in partial fulfillment of

the requirements of the degree of

MASTIR OF SCIENCE

in

BIOLOGY

Portland State University

1972 
TO THE OPICE OP GRADUATE STUDIES:

The members of the Committee approve the thesis of Brendan Pius onyejekre presented May $3,1972$.

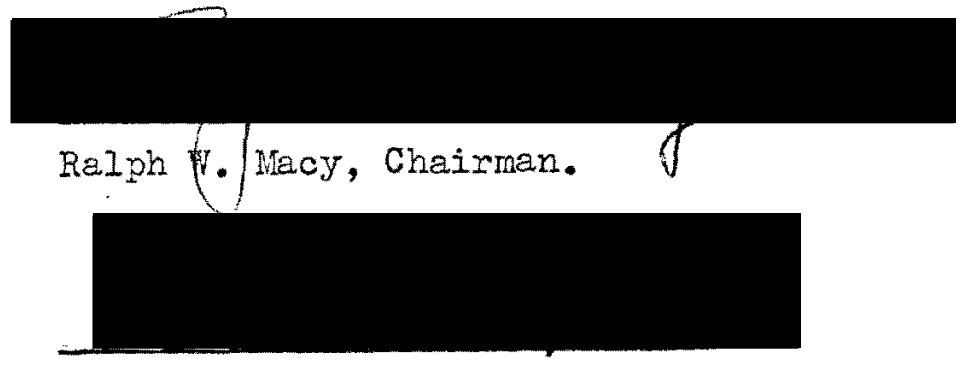

Leonard Simpson.
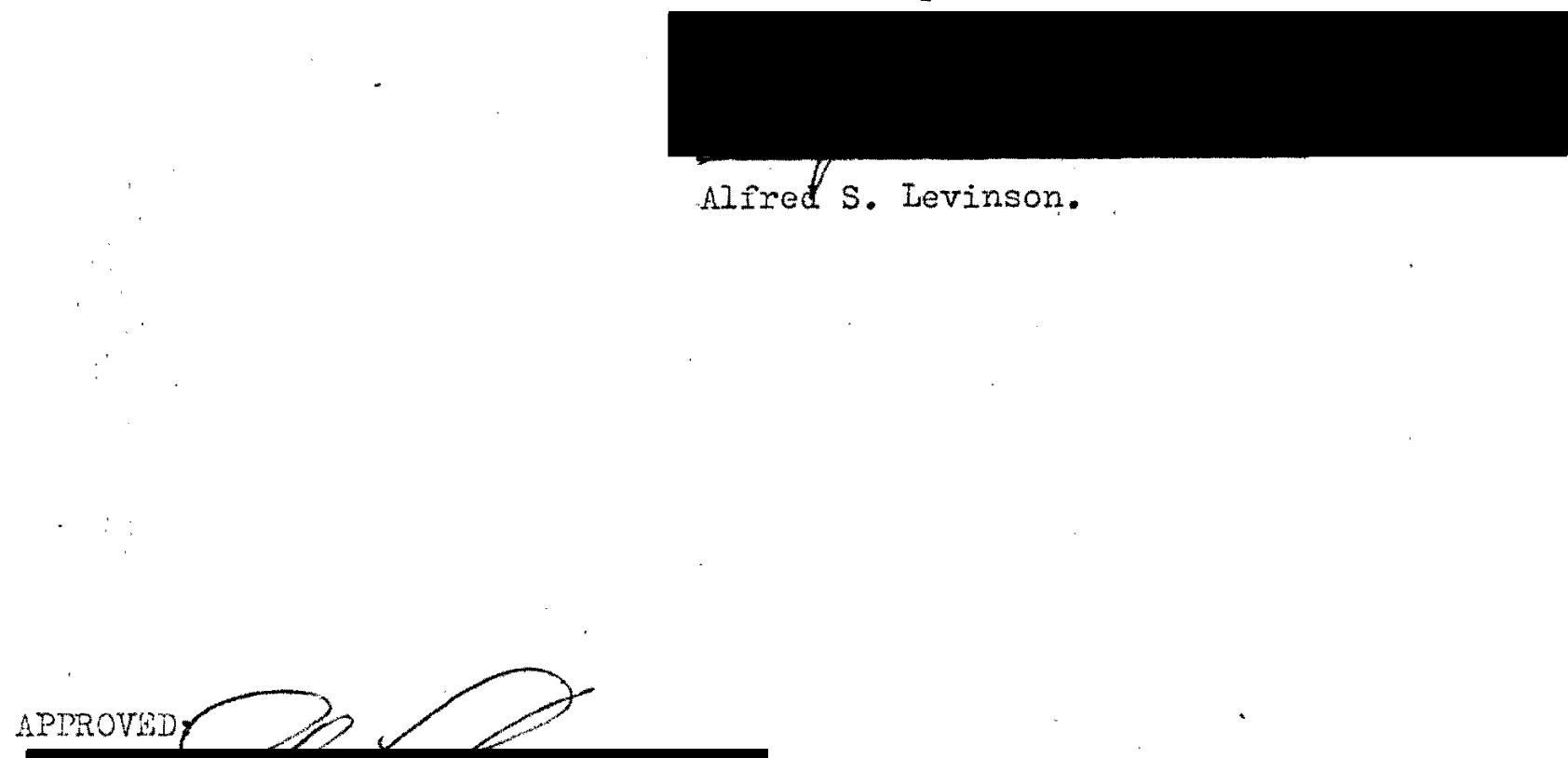

Earl Fishor, Head, Department of Biology

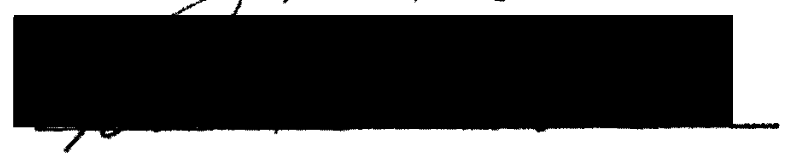

Drivid T. Clark, Dean of Graduate Studies and Research

Way 3,1972 
TABLE OF CONTENTS

PAGE

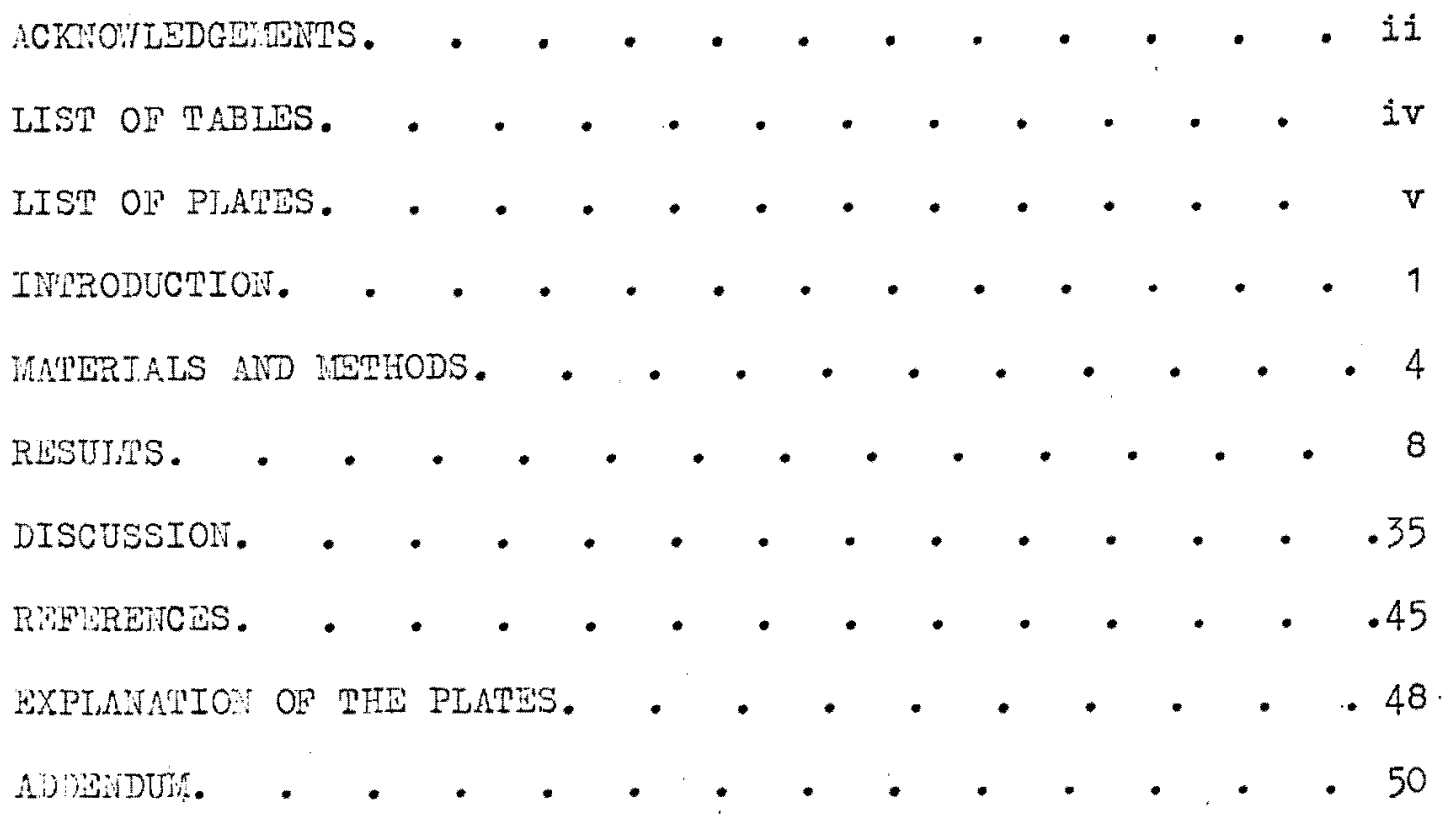




\section{- ACKTONLEDGETIENTS}

Thore ane many people to whom I am deeply grateful for their help during this work. I am very grateful to Dr. R. Macy for providing me the necessary advice and equipment. My thanks to Dr. I. Simpson who was always willing to talk with me over some tough technical difficulties, as well as lending me some equipment I lacked. My gratitude to R. Mikimoto of the Fish and Game Conmission, Portland, Oregon, for being very co-operative in making fish nets availoble to ne and also helping me in fishing. I also owe thanks to Dr. John Dash and Dr. Steon for their helpful advise on some technical problens. And, last but not least, my thanks to Rob Finlish for naking some reagents available to me whenever I asked for them. 


\section{LIST OF TABIES}

TABIE

I Incidence Record of Iissorchid Cercariae. • . 21

II Numbers of Cercariae Shed by Snails After Continuous

Exposure to Light and Darkness. . . . . . . 22

II Cumulative Number of Cercarize Shed in Fifteen Hours . 23

IV Sheding Rate of Cercariae of Lissorchis heterorchis from Plumenicola virens (Lea) by Day. . . . . 24

$\nabla$ Shedding Rate of Cercariae of Lissorchis heterorchis from Elumenicola virens by Night. . . . . . 25

VI Measurements of Cercoriae from 10 Experimentally Infected Snails itatched with Measurements of Cercariae from. Taturally Infected Snails. Measurements of the Eggs of Iissorchis heterorchis. . . . . . . . 26

VII A $2 \times 2$ Contingency Table of Flumenicola virens and Dusesia dorotocephala. . . . . . . . . 28

VII List of Endocommensals from Flumenicola virens. • . 30

IX Ileasurements of 13 Cysts. . . . . . . . 31

$X$ Keasurements of the length, width and ventral suckers of developing Lissorchis heterorchis. . . . $\quad 32$ 


\section{LIST OF PLATES}

PTALIS

PAGE

1 Drawing of the flame cell pattern, the gut of the cercaria and the sporocyst of Lissorchis heterorchis. - 9

2 Draving to show the germ cell primordia of the cercaria of Lissorchis heterorchis and the cross-section of the infocted glanaria to show the cyst. . . . . 10

3 'Developmental stages of the adult Iissorchis

hetororchis. . . . . . . . . . . 11

4 , Dorsal view of mature adult Iissorchis heterorchis (Courtesy of R. W. Mcy). • • • • • • . 12

5. A full life cycle draming of Iissorchis heterorchis. . 13

6 Drawing of an alternative second intermediate host

Chaetorastor limmaej, an annelid. . . . . . 14

7. Plot of the night time shedding rate of cercariae from

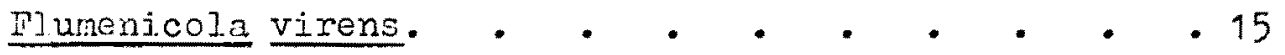

8 Plot of Daytime shedding rate of cercariae from

Flunenicola virens. . . . . . . . . 16

9 Plot of the cumulative number of cercaria shed from

Elumenicola virens. - . . . - . . . 17 


\section{INTRODUCTION}

A trematode, I,issorchis heterorchis Pfacy and Krygier (1969), collected from the suckers Catostomus macrocheilus Giard, in western Oresch was described by Krygier and hacy (1969) as a new species. The present investigation involves the life cycle of this species as vell as obscrvations on the second intermediate host reactions and the longevity of the parasite within the definitive host. The idea मas to recover the cercariae of Lissorchis heterorchis from both experimentally and naturally infected snails and allow them to infect the second intermediate host which was then fed experimentally to the definitive host. Another way of investigating this life cycle was to expose uninfected snails to the eggs from adult Lissorchis heterorchis for 21 hours in petri dishes and then release the snails into an aquerium for a period of time. Cercariae from these snails were allowed to infect the second internediate host after which the infected internediate host was fed to the definitive host.

Cort (1918) working on a cercaria he found in planorbis campanulatus gnithii Baker from Douglas Lake, Michigan, described it as Cercariaeum mutabilo, and succested its relationship to the sub-family Allocreadiinae Odhner. Later, Sewell (1922) in discussing the provisional group Cerchiaeum established the 'Mutabile Group' to which he assigned $\underline{\mathrm{C}}$. mutabilc Cort, $\underline{\mathrm{C}}$. limnaei obscuri Eroolani, $\underline{\mathrm{c}}$. paluãine Filippi and $\underline{\mathrm{C}}$. nlanorbis carinati Filippi. All of these develop in sausage shaped rediae without locomotor appendages. Thiey are devoid of a tail, have a long tubular excretory bladder and a pair of primary excretory tubules 
which pass forward to the region of the oral sucker or pharnyx and then rocurve and after a short course bifurcate into anterior and posterior secondary tubules which subdivide into tertiary tubules. In this group were included two cercariae, Cercariae Indicae VI and Cercariae Indicae IIV described by Sewell from India. Faust (1930) working on Corchiae sinense from China concluded that it was similar to Cercaria mutabile. From the descriptions of Cercariaeum No. 2 Peterson (1931) and Corcariecum A Kobayashi (1922), it appears that these also should be included in the "utabile" group even though very little detail is given in the description of either species.

Alhough a number of such related cercariae have been described, the only life cycle of these worked out so far is that of Cercaria mutabile, which has been shown by Wallace (1939) to develop into an adult which he assigned to the genus Prigandistornum Simer (1929). This genus is based on fifteen specimens from the intestines of the buffalo fish, Ictiobus bubalus Rafo, from the lower Tallahatchie River, Hississippi, to which Simer assigned the specific name, $\underline{T}$ translucens. Van Cleave and hueller (1932) added two more species to this genus, nanely $\underline{\mathbb{T}}$ attenatum and $\underline{T}$. Simeri, both from the intestines of Catostomus comnorsonnii Lnc. from Oneida Lake, New York.

Triganodiatomum was placed in the family Plagiorchiidae by Simer (1929) but Van Cleave and Hueller (1932) from evidences based on comparative morphology transferred it to the family Allocreadiidae. They had made an extended study of fish trematodes with lateral genital pores and on the basis of adult characteristics, concluded that Plamiornorus Stafford, Plagiocirmus Van Cleave and theller, Trimanodistomum Simer and Iissorchis Magath were closely related and can be 
placed in the same fanily.

Liscorchis Magath (1917) is the type genus of the sub-family Iiscorchinee which Magath suggested should be raised to the rank of a family Iissorchidae or placed with the family Plagiorchiidae provided the diagnosis of the latter were changed to include the sub-family Iissorchinae. Poche (1925) pointed out the many differences whon compering Lissorchis with the member of the family Plagiorchiidae and cstablished the family Iissorchiidae with Lissorchis Magath as type zen us.

From all descriptions, the type genus Iissorchis contains eleven described species of which only the life cycle of Iissorchis mutabile has been worked out fully. Smith (1968) investigating the same life cycle estabished that ancylid snails could also serve as first internediate host of lissorchis mutabile and were probably better suited cologically to serve as such hosts.

In a cocent comunication, R. M. Cable has expressed to Smith the opinion that the genera Lissorchis and Asymphylodora may belong in the family Zoomonidae because the morphology of their adults, aspects of the life cycle, and host-parasite relationships are more in agreement with that family then any other even though the zoogonids are marine. If substantiated, that view would invalidate, the Lissorchildae as a family but further information is needed to clarify its status and the affinities of its species with other trematode. 


\section{MTTERIALS AND IEREHODS}

Naturally infected snails, Flumenicola virens (Lea), and those used as a source of the stock culture, were collected from Crystal Sorings Creek and Tualatin Piver, in the Portland area, in large plastic cake dishes with fresh water. The collections were made over a period of one year. After each collection, the snails were hurriedly taken to the laboratory and maintained in dechlorinated tap water in acrated, 15 gallon aquaria with mud and dead plant matorial on the botton and some floating vegetation.

100-200 Flumenicola virens, from the Nehalem River where no nntural infection of the snails had been found, were also collected in a plastic cake dish with fresh water. These snails were left alive in this dish in a cold room until used. The snails served as the experimental first intermediate hosts.

Suckers used as experimental definitive hosts were gill or seine netted or trapped in fish traps from Rock Creek or lower Clackamas River. All were maintained in well aerated 5 gallon aquaria with al rae and some floating vegetation. They were fed on algae and occasionally fed with fresh water amphipods from Crystal Springs Creek. The fish aquariums were maintained at a temperature of $17 \pm 1^{\circ} \mathrm{C}$.

Wine adult suckers were gill-netted from near the bottom of the bridge at Multnonah Falls in mid-July, 1970. Examination of the intestines of these fishes showed that only one harbored adult worms of I,issorchis heterorchis. The recovered adult worms were teased apart quickly in $0.6 \%$ saline, to release the eggs. Fifteen uninfected 
snails from the Wohalen River (noninfection of the snails was confirmed by placing fifteen snails together in a plastic petri dish for seventytwo hours in an environmental chamber and observing whether or not they discharged lissorchid cercariae) were each exposed in seperate petri dishos containing eggs (twenty or more) of the adult Lissorchis hotcrorchis in dechlorinated water for seventy-two hours.

The snails were incubated in a 5 gallon aerated aquarium for six weeks and at the end of the sixth week the snails were seperated into petri dishos with chlorinated water and allowed to discharge cercariae in an environmental chamber. Uninfected planarians, two per petri dish, were exposed to tro of the discharging snails in the petri dishes with wator for forty-eight hours. Infection of planaria vas assessed by looking at specinens on slides covered with cover slips under a low power lens.

The experimental cercariae were matched with naturally occurring cercariae on the basis of morphology and infectivity for Dugesia dorotocephala (Woodworth). Several snails, Flumenicola virens were trus infected. Infection of the experimental suckers was done by putting Finely cut pieces of infected planaria down the intestine of the experinental fishes. Another sucker was fed with the eggs and cercariae directly to see if infection was possible. For longevity studies, a sucker was fed infected planaria and left in an aquarium for 4 to 5 weeks. Sone of the infected planaria were fixed in warm Bouin's fluid, embedded in paraffin for serial sections. The sections were stained in Harris' alum haematoxylin and mounted in Harleco synthetic resin. liounted sections were examined under low and high power magnification. Permanent mounts of the cercariae were made by pipetting six to 
seven larvae onto a glass slide $(75 \mathrm{~mm} \times 23 \mathrm{~mm})$ sprayed with Haupt's solution and then covering the cercariae with a drop or two of $80 \%$ alcohol. The treated slides were left for twenty-four hours to dry. After drying, the slides were then hydrated and stained in Harris' alum Reamatoxylin, dehyárated and mounted in S.S.R. resin. Measurements of cercariae were made from specimens killed in hot $10 \%$ Formalin and stained in neutral red. Measurements are in microns unless othervise stated. Averages of each stage were followed by minima and maxima in parenthesis.

Shedding period of the snails was studied using individual, shedding: cnails in seperete petri äishes with dechlorinated water. Five alreadyto-shed snails were introduced into individual petri dishes with overnight wetor and hourly counts of the cercariae were made starting from $5 \mathrm{pm}$. In another experiment counts were taken starting from 7 am until $9 \mathrm{pm}$. Nt the end of every hour, each snail was transferred to a new petri dish with dechlorinated water and the cercariae in the previously used petri dish counted. At night, the transfer was done in darkness using the red flash light momentarily to aid in the transfer. The counts of the cercarial discharge wes tabulated. The cumulative counts from one of the snails vere plotted.

The effect of continuous light and continuous darkness, was studied by putting shodding snails in petri dishes with dechlorinated water in continuous light and later continuous darkness for forty-eight hours. Drawings of the rediae and sporocysts were made with the specimens in $0.2 \%$ saline solution at room temperature on a glass slide. The flame cell pattern of the cercariae was worked out by placing cercariae in a drop of $0.6 \%$ saline on a slide covered with a cover slip and applying 
a drop of aqueous Wile Blue Sulphate at one end of the slide.

In live infected planeria measurements of thirteen cysts were made and in seven occasions the cysts were disected out using fine dissecting pins in $0.2 \%$ saline to study the morphology of the metacercarae and the moverients.

Ir: Crystal Springs Creek where naturally infected snails occur, the rocks and pebbles were picked up and examined closely for planarians. Counte of plenarians and snails - Flumenicola virens occurring in the same quadrat were telken for the months of July and August, 1971, and tabulated in a $2 \times 2$ contingency table.

Planarians taken from the areas of Johnson Creek where the snails are noturally infected were collected in little glass jars containing water ard taken to the laboratory for examination. The planarians were examined as already described.

Using the dip net, fishing for the definitive hosts, rough-scaled suckers were done by dipping the net down to the creek bed and moving the net forwards against the current.

Dramings of the cercariae and the developing stages within the fish were made using the camera lucida. Drawings of the paratype adult and the cross-section of the planaria were made onto a square paper to maintain proportions. 


\section{BESULTS}

- Adults Lissorchis heterorchis recovered from Catastomus macrocheilus Girard have been described by Macy and Kryorier (1969). The diagnosis of the adults recovered from naturally infected Catostomus macrocheilus by the writer match very weil with that of Macy and Krygier (1969). The life history in brief is this: the cercaria develop in sausage shaped rodiae in the snails Flumenicola virens and planaria serves as the second intermediate host. The worms reach maturity in the anterior third of the intestine of the rough-scaled sucker. Strges in the Tife Cycle:

Corcaria (P1. 2.1)

Diagnosis: Microcerous cercaria. Body of ten cercariae killed in hot 10\% avoraged $248(176-320)$ lons by $92(64-120)$ wide. There were no cuticular spines on the entire body except at the tail where the spines are arranged in alternating roms over the surface of the tail. Oral sucker is as wide as it is long $44(32-56)$. Pharynx 24 long by 16 wide. The oesophagus descends down to near the acetabulum before it bifurcates and circumvents the acetabulum and each branch ends in the posterior third of the body. They are clustered just above the acetabulum as shown in the draming (Pl. 2.1). The ducts coming from these penetration glands are clearly seen in live specimens in $0.6 \%$ saline solution under oil immersion lens. They open on the side of the oral sucker through seperate ducts. The thick walled S-shaped cxoretory duct is clearly visible even under low powcr. The details of the flane cell pattern was worked out and found to have the flame 


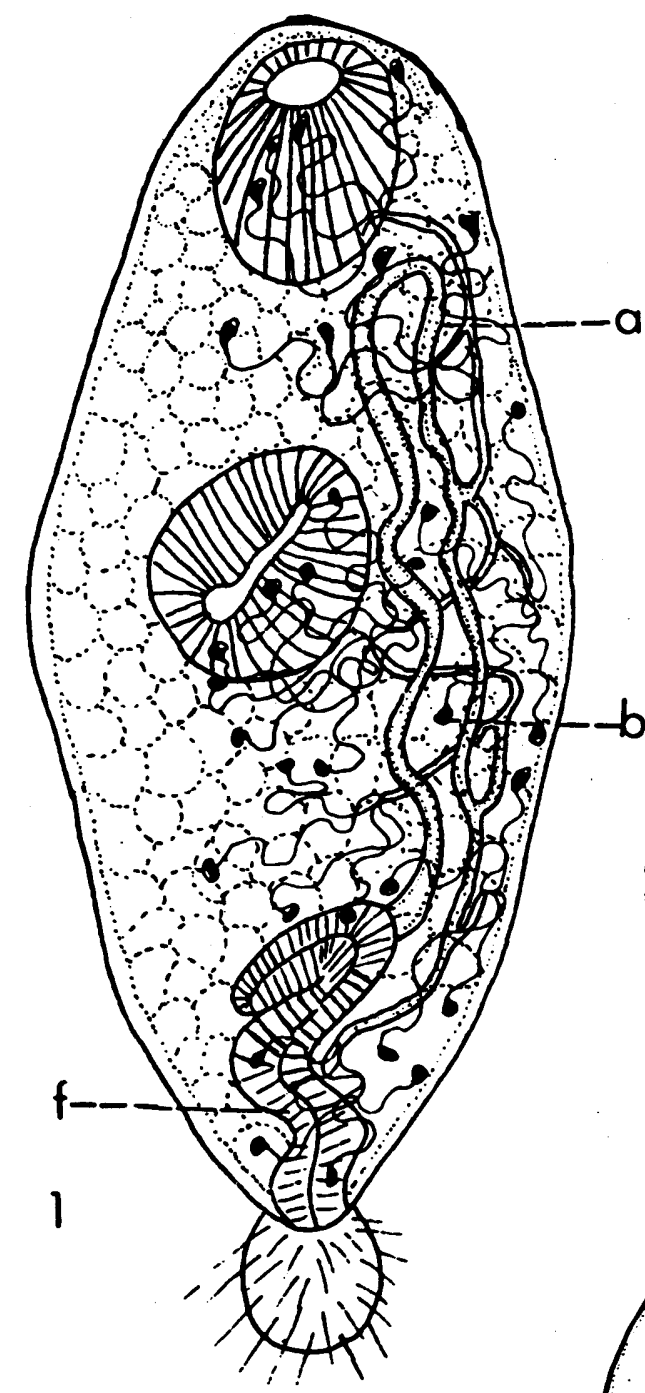

Plate 1

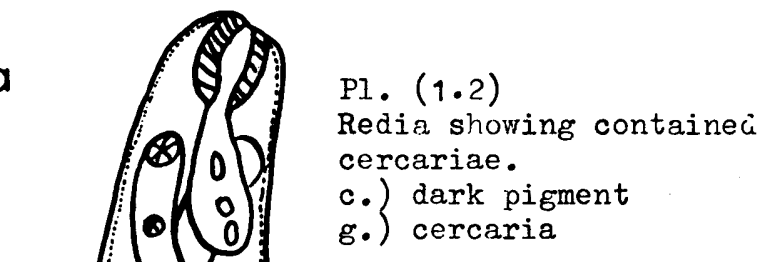

P1. $(1 \cdot 1)$

Lissorchis heterorchis cercaria, flame cell pattern.

a. excretory tubule

b. flame cell

f.) excretory bladder (left side of flame cells is omitted)

2
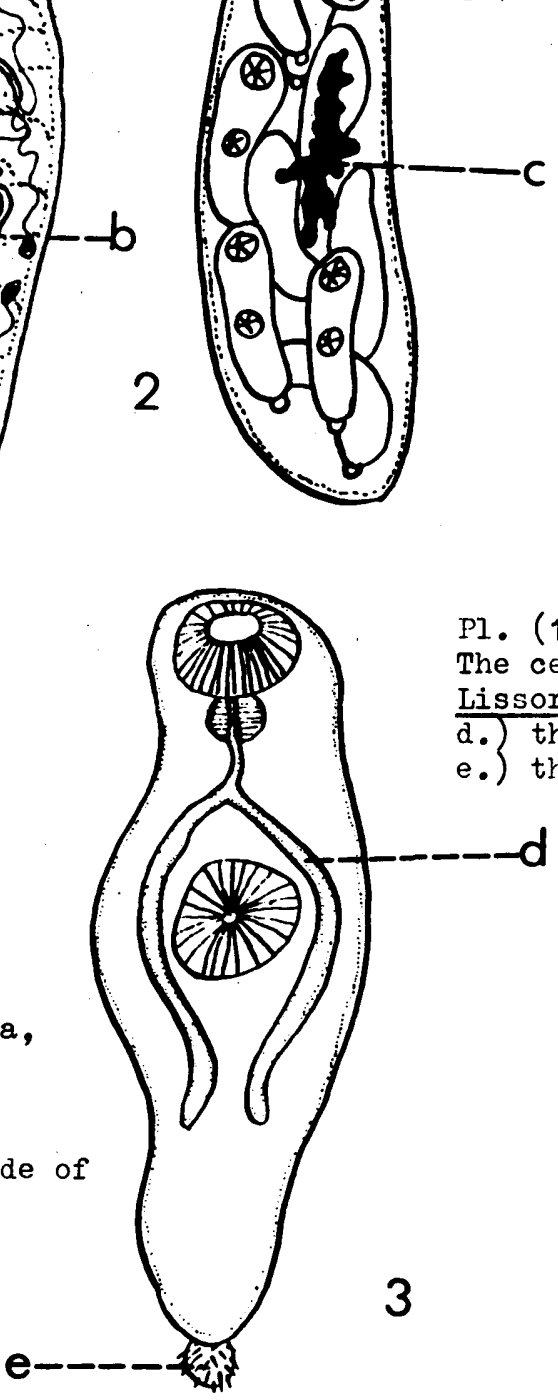

PI. $(1 \cdot 3)$

The cercaria of

Lissorchis heterorchis d. the gut

e. the spined tail 

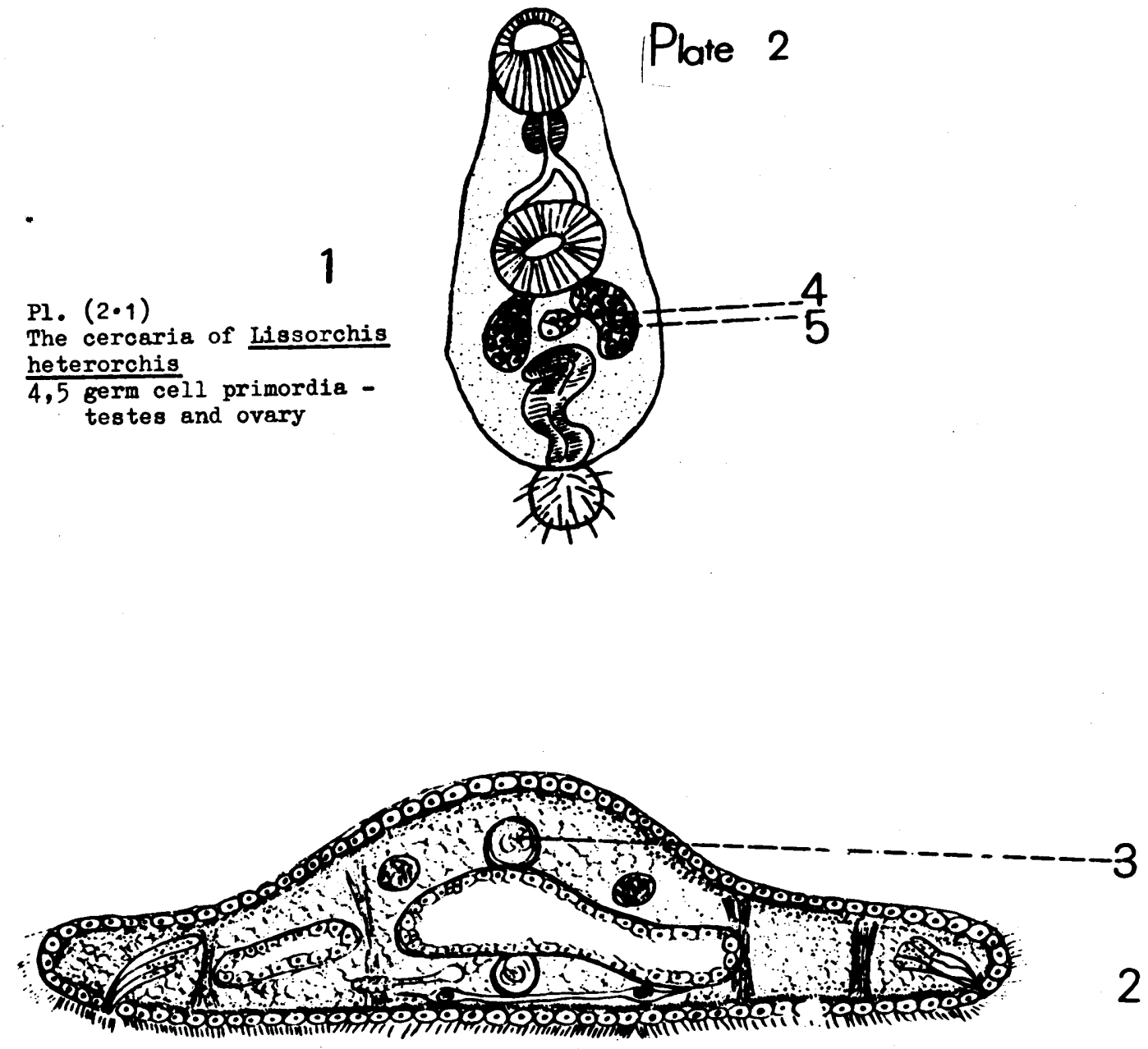

P1. $(2 ; 2)$ Cross section of the infected planaria Dugesia dorotocephala 3 , cyst 


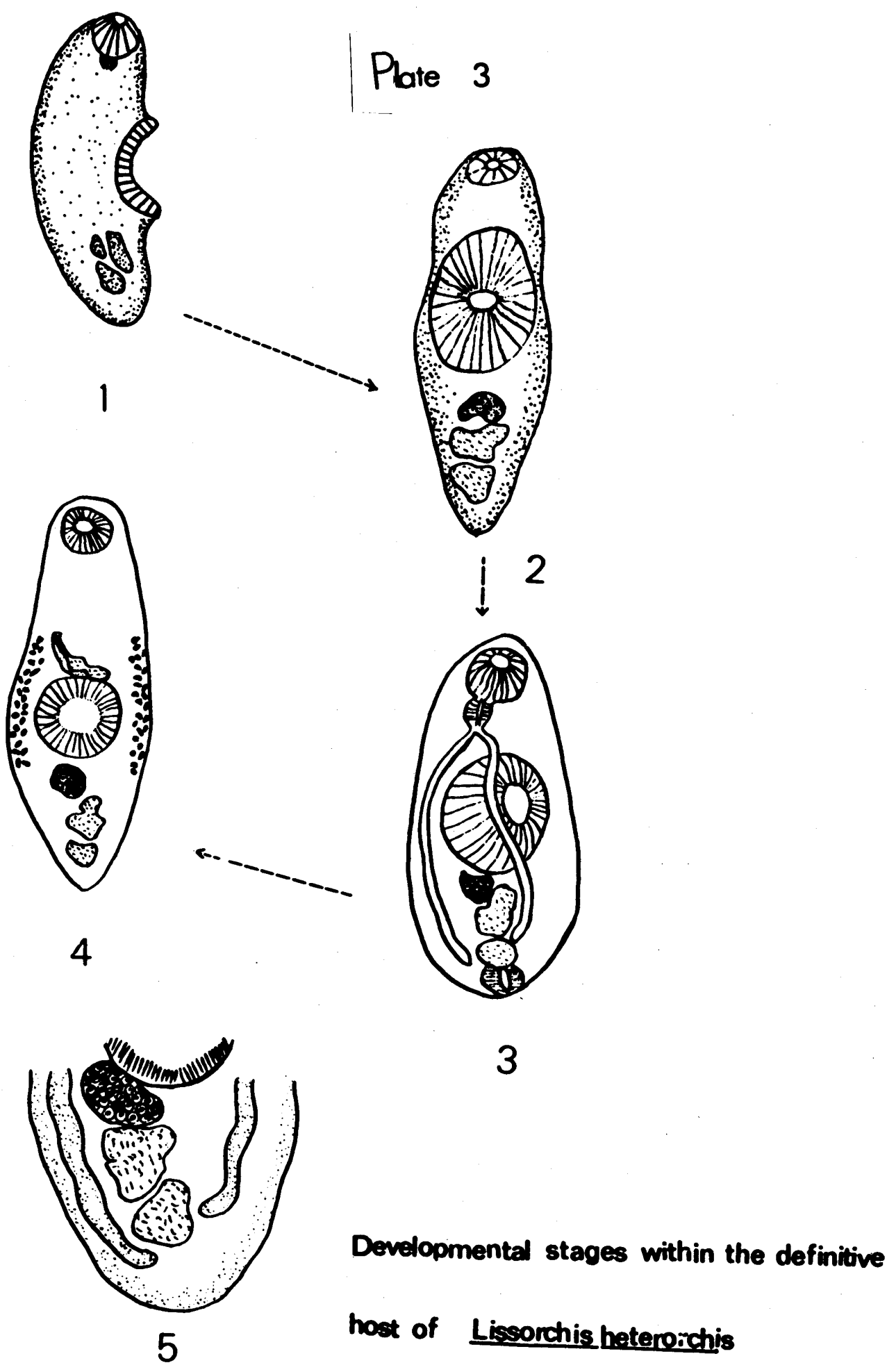


12

|Plate 4

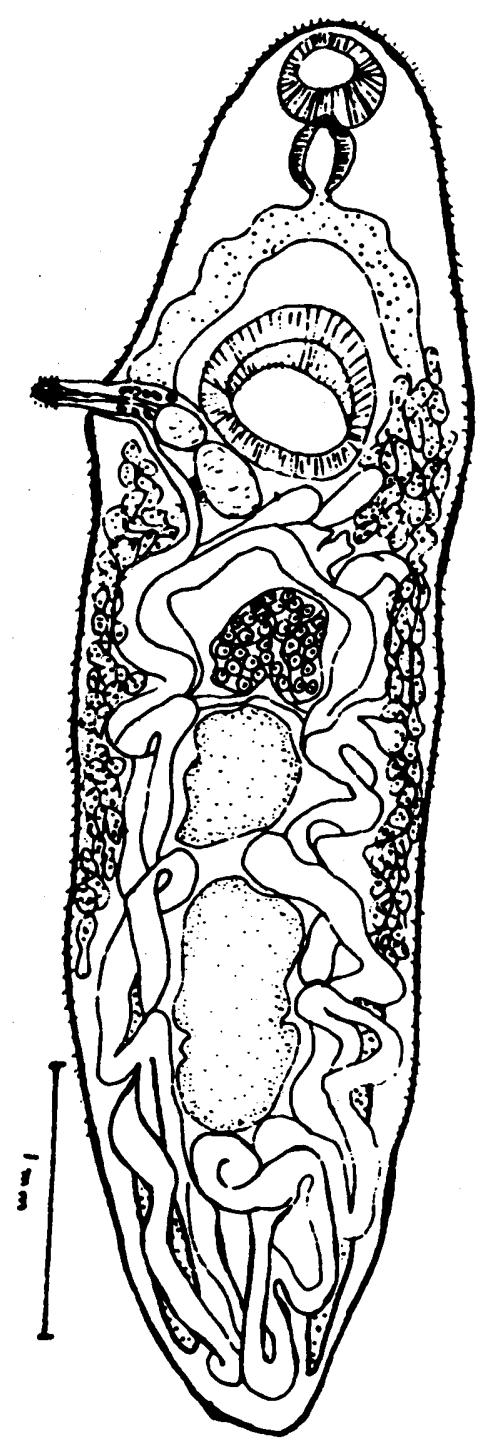

Lissorchis heterorchis Macy and Krygier, paratype dorsal view 
Plate 5

Life cycle of Lissorchis heterorchis

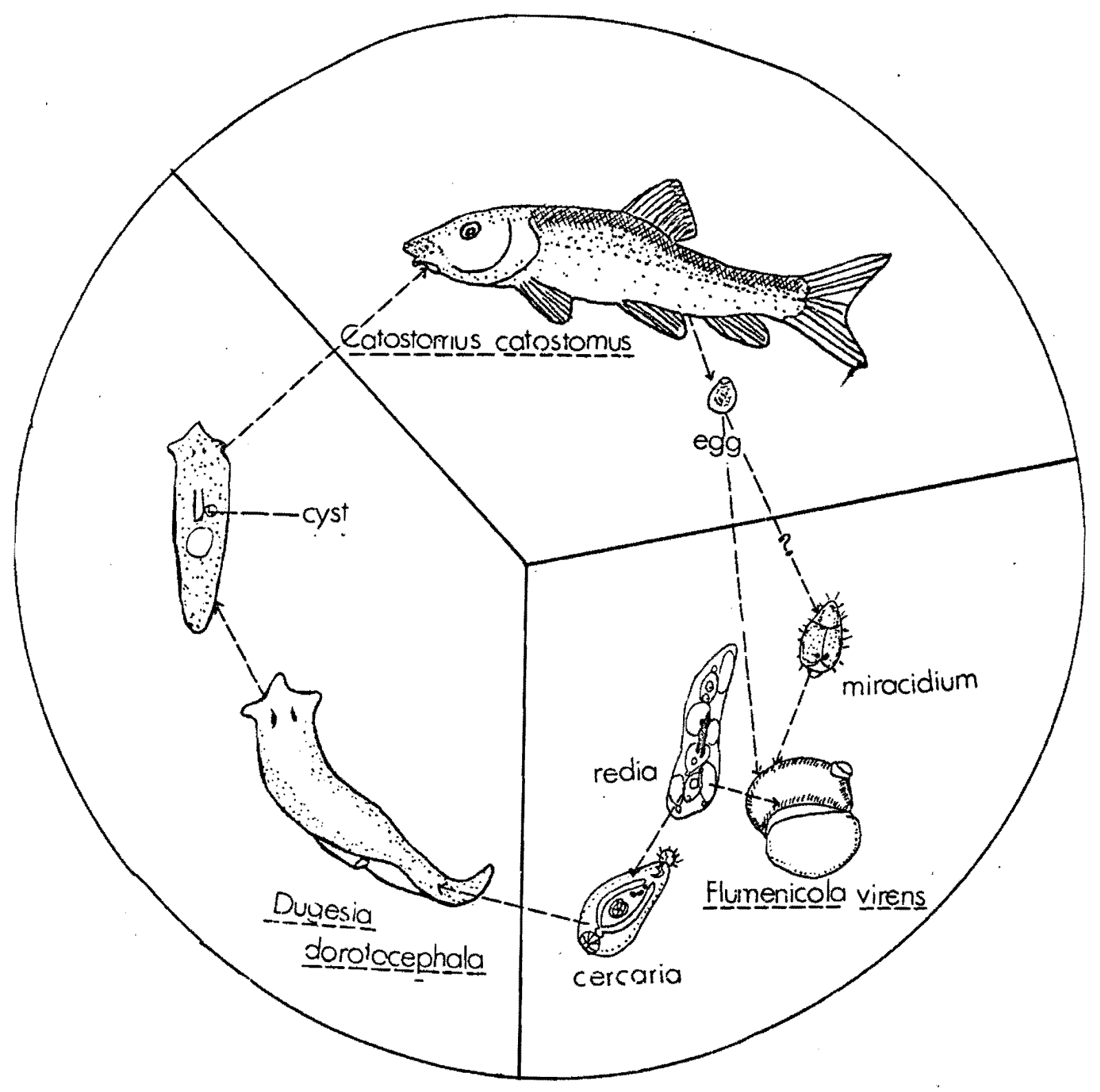




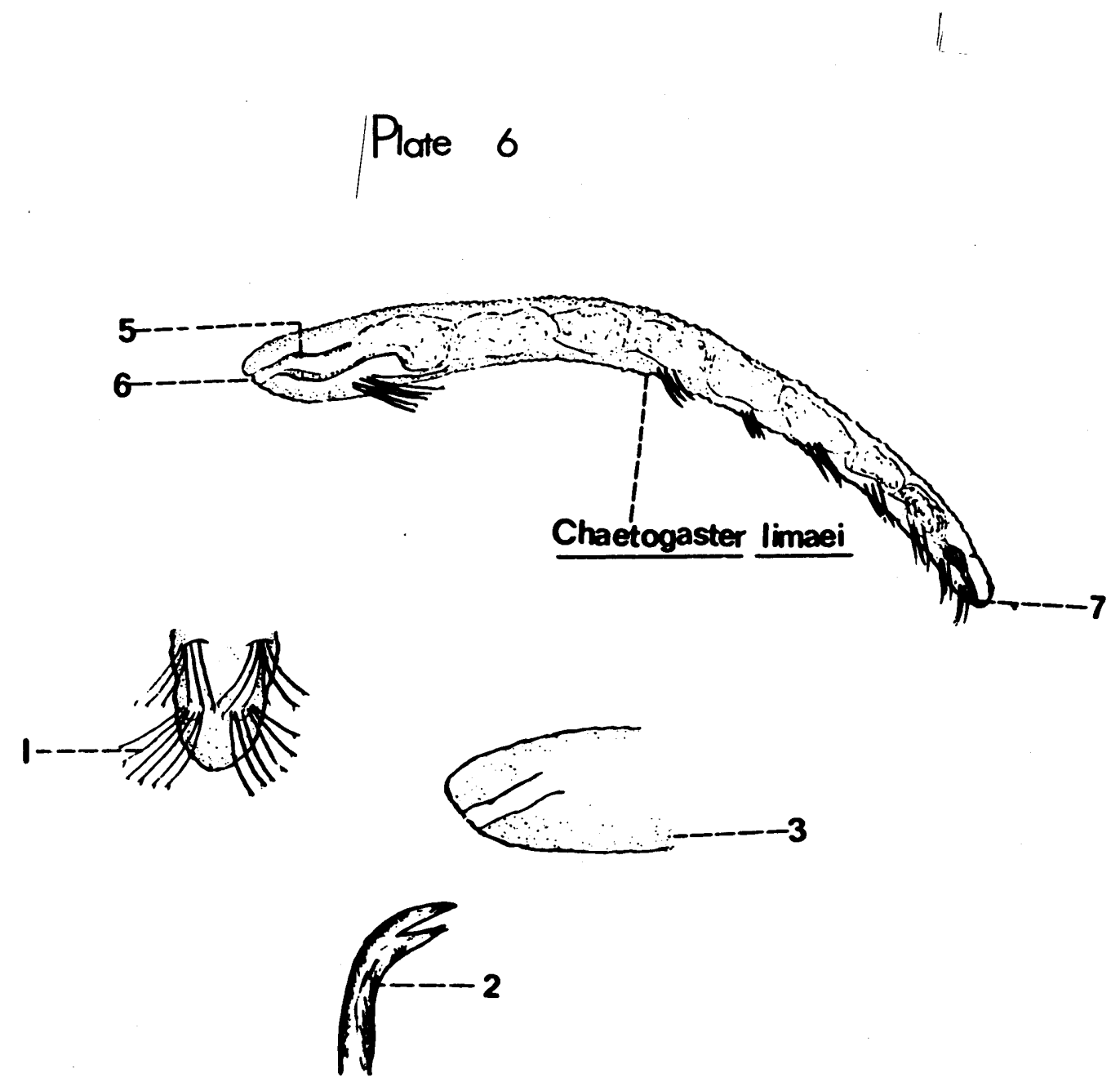

Drawing of alternative second intermediate host Chaetogaster limnaei.

Pl. $(6 \cdot 1)$ posterior of the organism showing arrarigement of bifurcate spines.

Pl. $\{6 \cdot 2\}$ an enlarged drawing of a spine:

PI. $(6 \cdot 3)$ anterior end of the worm.

$\mathrm{PI}$ : (6.5) the pharynx.

PI. $(6 \cdot 6)$ the mouth. 


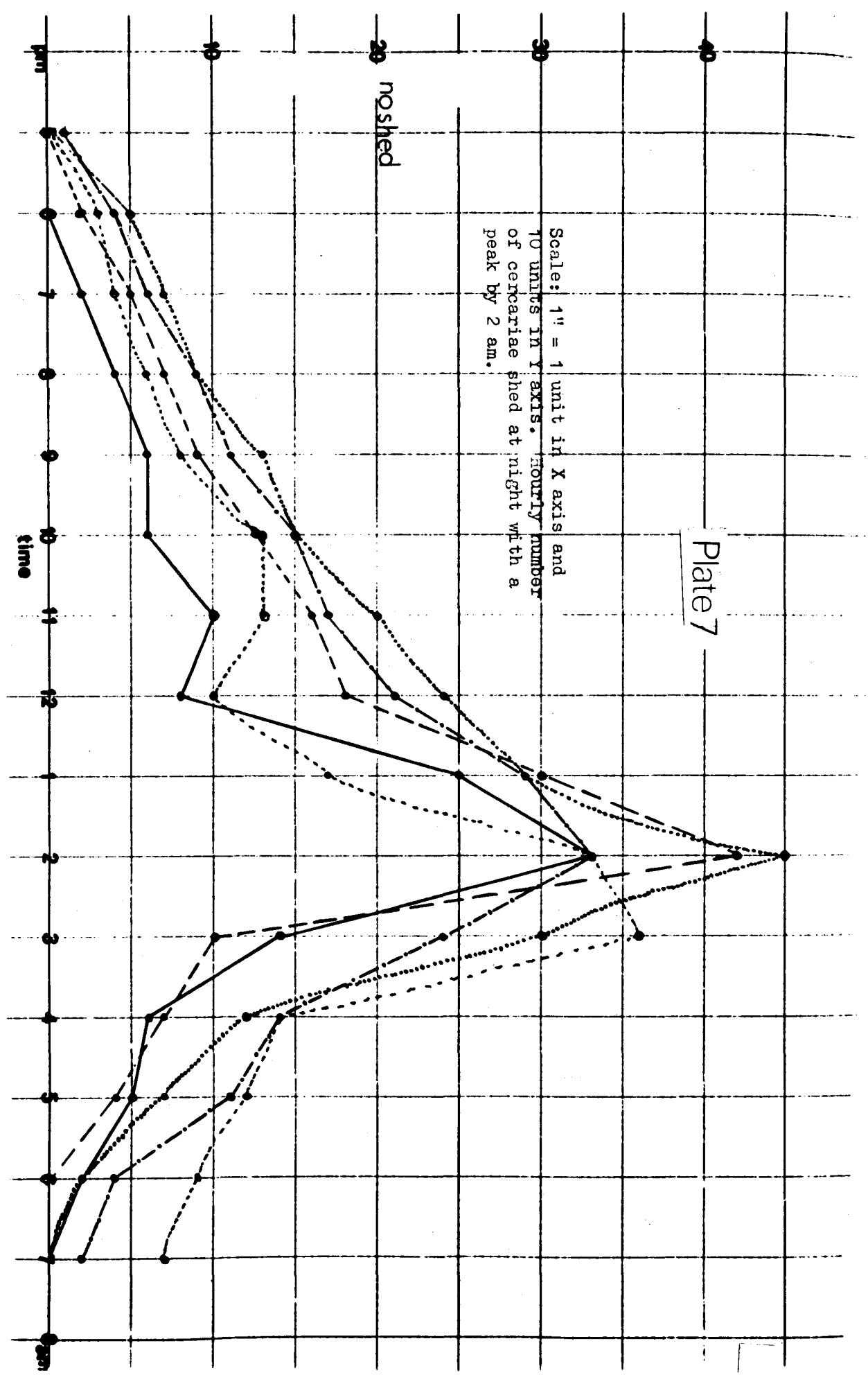




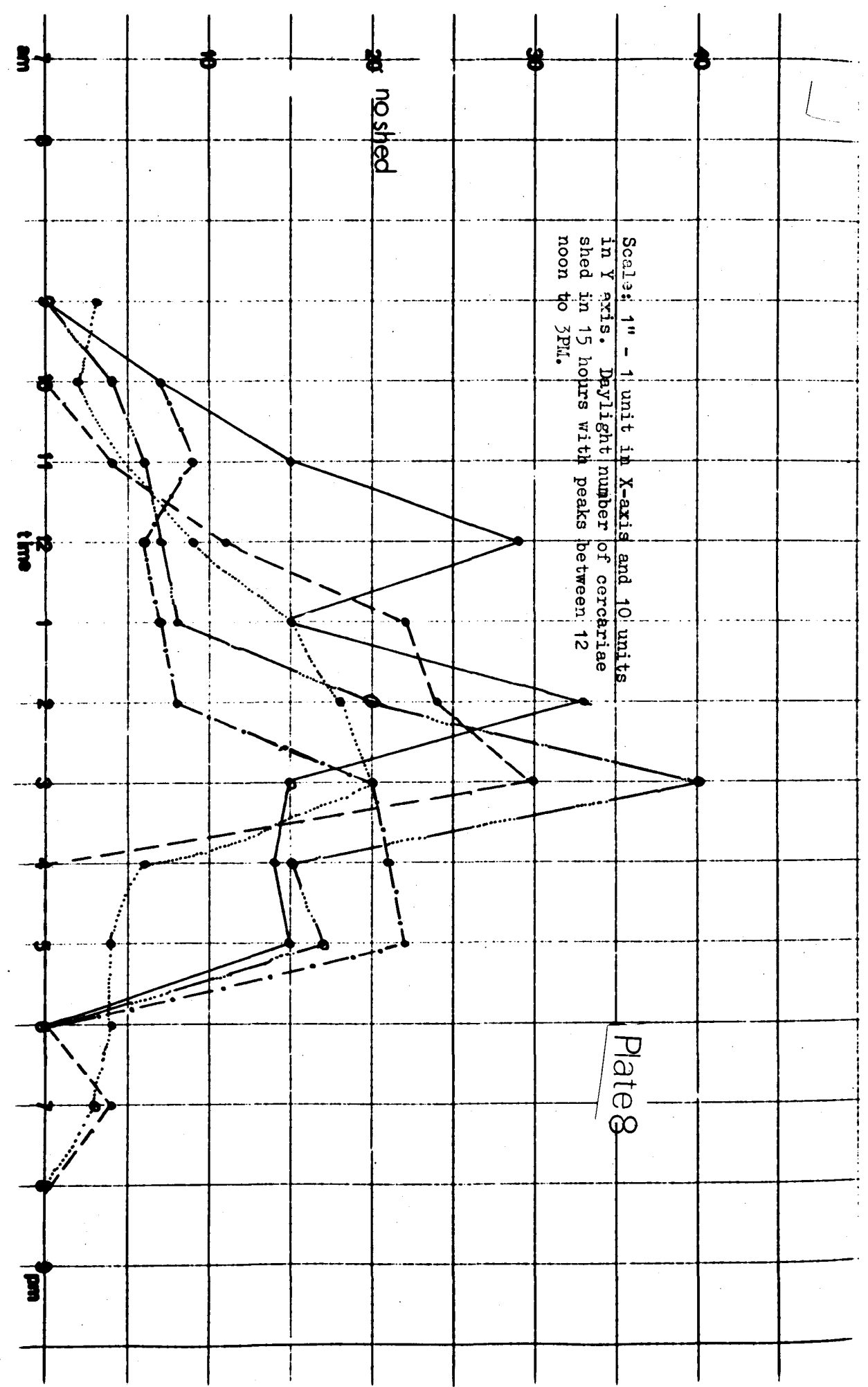




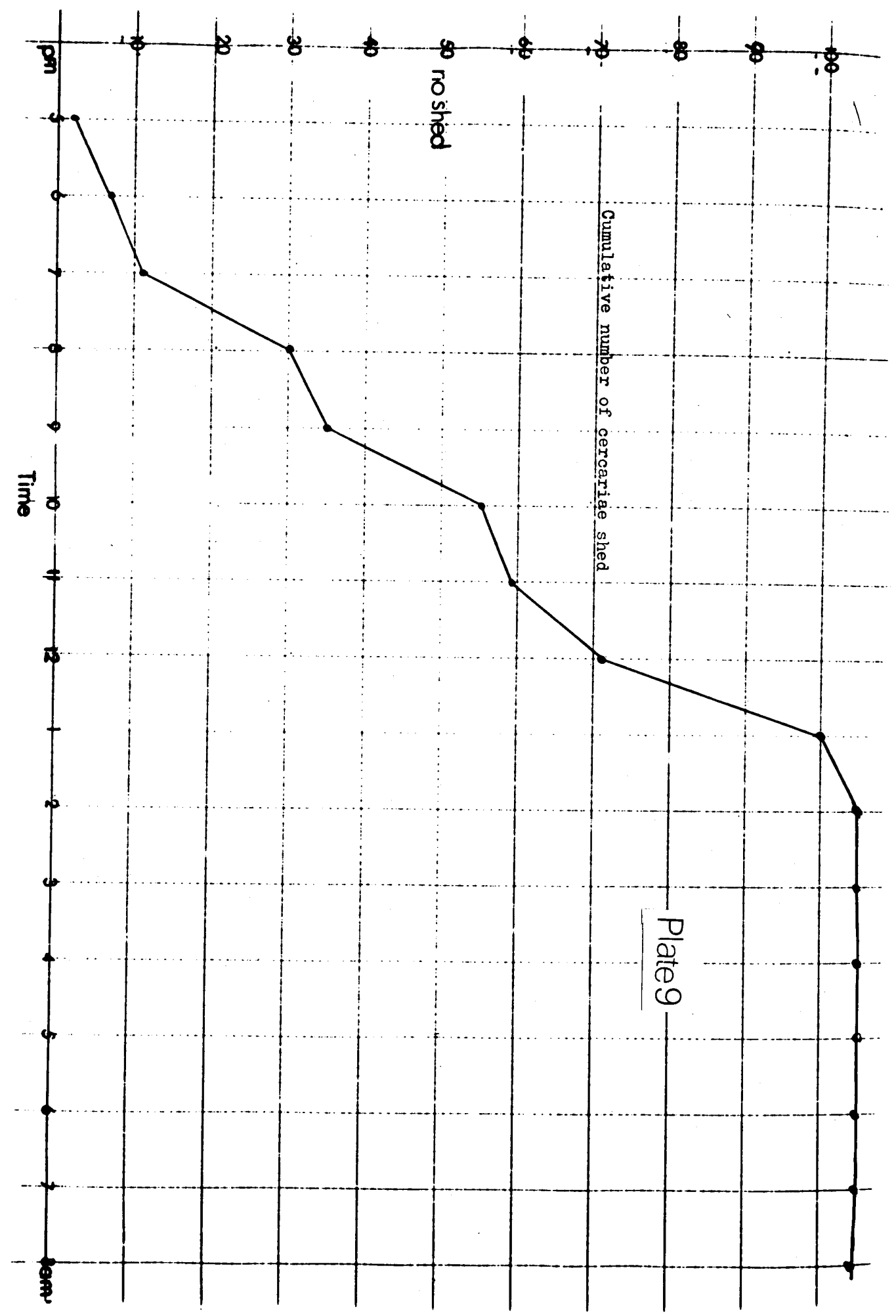


cell patiern $2[(2+2+2+2)+(2+2+2+2)]$. Typical arrangement of the flame cells is as in PI. 1.1. Measurements of the life cercariae is Given in Table VIA.

Host: Inresia dorotocephala (Woodworth)

Localiby: Tualatin River, Crystal Spring Creek, liultnomah County, Orogon.

Observations on this cercaria was made between June, 1960, to Novornber, 1971, in the laboratory in the Biology Department, Portland. State University. The incidence of this cercaria occurs all the year round in the nared localities but the incidence is slightly higher in springs and sumer months.

The cercaria does not swim too actively but crawls on the bottom. It is capable of extensive elongation. It can live at room temperature up to thirty-six hours after which it dies and swells, due to intake of water. The primordia of the reproductive organs show considerable development. The ovary and the testes lie in this order behind the scetabulum. The testes are opposite.

The rediae, located in the digestive gland of the snail, are usually eloncate and slightly curved and were without termal constrictions. The redia has a black band in the middle. The highest number of cercariae found so far in each redia was fifteen. Measurements of eight redjae indicate that the length ranges from 400 to 488 and the widt Srom 240 to 280. The pharynx measures $36(32-40)$ Iong and 24 $(16-32)$ wide (P1. 1.2). The gut has a faint outline and it is filled with refractile granules. There apparently is no socond generation redjae. The birth pore is located near the pharnyeeal region as observed from cercariae escaping from rediae. No sporocyst but the 
prescnce of the black pigment in these early stages indicate that they are rediae in which the cercaria have not been formed. These early stasos cortain granular substances embedded in a cytoplasmic mass. ino information is available about the morphology of the miracidium. The eEs of a gravid Lissorchis heterorchis is small and operculate. The egr measures $22(20-24)$ long and $12.5(10-15)$ wide. The egrs hatch by flipping open the operculum as observed from one ege hatching in distilled rater.

Work done by Hacy (1960) on the shedding period of cercariae of p. vespertilionis parorchis Braun, shows that the peak of shedding in that species is at night near $1 \mathrm{Am}$. Investigations on the shedding period of cercaria of Lissorchis heterorchis shows that there are two poaks of shedding one by 1 PM and another by $1 \mathrm{AM}$. It was observed (PI. 7) that five snails shed their maximum numbers of cercariae during the hours of 11 par, midnight, 1 All and 2 Ail. It was also observed (PI. E) that another batch of five snails shedding the cercariae of Lissorchis heterorchis shed their maximum numbers of cercariae during the hours of $11 \mathrm{Ait}$, noon, $1 \mathrm{PM}$ and $2 \mathrm{PH}$.

Exposure of the shedding snails to continuous light and continuous darkness for forty-eight hours shows that continuous light inhibits cercarial shedding and that continuous darkness promotes shedding. (Tabio II).

Finuenicola virene shedding cercariae of Iissorchis heterorchis were also found to shed endo-commensals belonging to the class Ciliata and'Chnetogaster limnaei (Plate 6), an annelid, and in no case were corcariae other than those of Lissorchis found. The ciliates and the amelicis vere keyed out as far as possible to the genus or species level 
TABLE I

THE IICIDETCI RECORD OP LISSORCHID CERCARIA IN 7,200 SNAILS IS

EXMIIED

Period (1970-72)

$\begin{array}{cccc}\text { No. of Snails Examined } & + & - \\ 2,400 & 72 & 2328 \\ 2,000 & 60 & 1940 \\ 2,000 & 64 & 1940 \\ 800 & \underline{20} & \underline{776} \\ & \text { Total } & 216 & 6984 \\ \%=3 & & \end{array}$

THE IHCTDEMCE RECORD OF INETACERCARIAE IN BROHN PLANARIANS EXAMINED

Period

Jinuary 14 - Warch 14 No. of Planarians Examined +

My $15-$ July 15 90

288

August 17 - November 17

90

486

November 18 - January 14

90

$3 \quad 87$

+ Containing larval stages of Lissorchis heterorchis

- No larval stages present 
TABIE II

ITUIBHES OF CERCARIAE SHED BY

SMAILS AFTER CONTIINUOUS

IXPOSURE TO LIGHT

MID DARKIESS

$\begin{array}{ll}\text { Snoil } & \text { Nof cercariae shed } \\ \text { (continuous light) } & \text { No. of cercariae shed }\end{array}$

\begin{tabular}{lll}
\hline 1 & 65 & 200 \\
2 & 50 & 175 \\
3 & 27 & 165 \\
4 & 21 & 113 \\
5 & 41 & 140 \\
6 & 49 & 157 \\
7 & 29 & 144 \\
8 & 43 & 152 \\
9 & 44 & 171
\end{tabular}


TABIE III

CUNTLATIVE NUMBIR OF CERCARIAE SHED

Start

5 P.I

6

7

8

9

10

11

12

1

2

3

4

5

6

7

8
Number Shed

2

7

11

30

35

55

59

71

100

105

105

105

105

105

105

105 


\section{TABLE V}

SHTDDIIG OF CERCARIAE OF LISSORCHIS

BETERORCIIS FROR PLUMENICOLA VIRENS

Aug. 14, 1971

\begin{tabular}{|c|c|c|c|c|}
\hline Start & $\Delta$ & B & $\underline{C}$ & $\underline{D}$ \\
\hline $5 \mathrm{PH}$ & - & - & - & 1 \\
\hline 6 & 2 & - & 5 & 4 \\
\hline 7 & 5 & 2 & 7 & 6 \\
\hline 8 & 7 & 4 & 9 & 8 \\
\hline 9 & 9 & 6 & 13 & 11 \\
\hline 10 & 13 & 6 & 15 & 13 \\
\hline 11 & 16 & 10 & 20 & 17 \\
\hline 12 & 18 & 8 & 24 & 21 \\
\hline 1 & 30 & 25 & 29 & 29 \\
\hline 2 & 42 & 33 & 45 & 33 \\
\hline 3 & 10 & 14 & 30 & 24 \\
\hline 4 & 7 & 6 & 12 & 19 \\
\hline 5 & 4 & 5 & 7 & 11 \\
\hline 6 & - & 2 & 2 & 4 \\
\hline 7 & - & - & 1 & 2 \\
\hline 8 & - & - & - & - \\
\hline
\end{tabular}


TABIE VI A

\section{TEASUREIENTS OF CERCARIAE FRON EXPERIMEITALIY \\ INEECTED SNAILS - 10 CERCARIAE}

\begin{tabular}{|c|c|c|c|c|}
\hline $\begin{array}{l}\text { Diameter } \\
\text { of oral } \\
\text { sucker }\end{array}$ & $\begin{array}{l}\text { Body } \\
\text { Length } \\
\end{array}$ & $\begin{array}{l}\text { Body } \\
\text { Width } \\
\end{array}$ & $\begin{array}{l}\text { Diameter } \\
\text { of ventral } \\
\text { sucker }\end{array}$ & $\begin{array}{l}\text { Tail } \\
\text { Diam. }\end{array}$ \\
\hline 32 & 224 & 64. & 48 & 9.6 \\
\hline 32 & 224 & 56 & 48 & 12.0 \\
\hline 56 & 296 & 120 & 64 & 16.0 \\
\hline 10 & 200 & 96 & 32 & 12.0 \\
\hline 40 & 200 & 96 & 32 & 12.0 \\
\hline 32 & 224 & 64 & 48 & 10.6 \\
\hline 40 & 200 & 96 & 32 & 10.6 \\
\hline 48 & 288 & 112 & 40 & 12.0 \\
\hline 48 & 288 & 112 & 40 & 12.0 \\
\hline 56 & 296 & 120 & 48 & 16.0 \\
\hline$\overline{42.4}$ & $\overline{244}$ & $\overline{93.6}$ & $\overline{43.2}$ & $\overline{12.28}$ \\
\hline
\end{tabular}

Standard deviation for the body length $=42.5$

Standard deviation for the body width $=24.3$

heasuremonts from naturally infected snails

$\begin{array}{lrrrr}48 & 176 & 38 & 32 & 9.6 \\ 48 & 296 & 120 & 38 & 20.0 \\ 32 & 240 & 80 & 48 & 16.0 \\ 56 & 320 & 112 & 40 & 16.0 \\ 40 & 240 & 80 & 48 & 12.0 \\ 40 & 200 & 96 & 32 & 10.6 \\ 32 & 224 & 64 & 48 & 12.0 \\ 40 & 200 & 96 & 32 & 12.0 \\ 48 & 288 & 112 & 56 & 16.0 \\ \frac{52}{43.6} & \frac{296}{248} & \frac{120}{96.8} & \frac{64}{42.8} & \frac{-12.42}{12} \text { mean }\end{array}$

Standard deviation for body lenth $=49.5$

Standard deviation for body width $=18.2$

It is hypothesized here that the mean of the body lengths for the cercariae from naturally infected snails and from experimental cercariae are not significally different: 
TABIE VI B

$$
\begin{aligned}
& \mathrm{H}_{0}: u_{1}=u_{2} \\
& \mathrm{H}_{\mathrm{d}}: \mathrm{u}_{1} \neq u_{2} \text { at } 5 \% \text { level and at } 1 \% \text { level } \\
& t(.025)(18)=1.74 \\
& t(.005)(18)=2.895 \\
& t=\sqrt{\frac{\left(\pi_{1}-\bar{\nabla}_{2}\right)-\left(u_{1}-u_{2}\right) \cdot}{\operatorname{sp}\left(1 / n_{1} \div 1 / n_{2}\right)} \cdot 1} \cdot 1 \\
& S P=\sqrt{\frac{(n-1) s_{1}^{2}+\left(n_{2}-1\right) s^{3}}{n_{1}+n_{2}-2}} \\
& \frac{\sqrt{(9 \times 42.5)+(9 \times 49.5)}}{18}=6.8 \\
& \text { substituting in (1) } t=1.39
\end{aligned}
$$

So we do not reject the hypothesis. Similarly for all other measurenent at $5 \%, 1 \%$ significance level, we do not reject. Hence, the two cercuriae match statistically.

incasurcments of 10 eggs from adult Lissorchis heterorchis. ilossuroments of ten ings

$\begin{array}{cr}\text { Lenath } & \frac{\text { Width }}{9.6} \\ 24 & 9.6 \\ 20 & 10.4 \\ 20 & 11.2 \\ 24 & 15.0 \\ 20 & 12.0 \\ 20 & 15.0 \\ 20 & 10.4 \\ 20 & 12.0 \\ 20 & 12.0\end{array}$


TABIE VII A

A $2 \times 2$ contingency table showing observed frequencies of Plumenicola virche (Lea) and Dugesia dorotocephala (Woodworth) in two sample areas I and II. The figures in parenthesis are the expected frequencies. Samples are analyzed below. Table IA is for the ronth of July and Table IB is for the month of August.

$$
7 / 7 / 71
$$

I

\begin{tabular}{ccc}
$I \quad 12(11.08)$ & $8(6.98)$ & 20 \\
II $\quad 16(17.06$ & $(0.02)$ & 23 \\
\hline 28 & 15 & 13 \\
\hline
\end{tabular}

TABLP IA
$8 / 7 / 71$

II

\begin{tabular}{lll}
$I \quad 8(8.32)$ & $6(5.68)$ & 14 \\
II 14(13.68) & $9(9.32)$ & 23 \\
\hline 22 & 15 & 37 \\
\hline
\end{tabular}

TABIE IB

\begin{tabular}{|c|c|c|c|c|c|c|c|}
\hline $\begin{array}{l}\text { Ous. } \\
\text { Troq. } \\
\text { o }\end{array}$ & $0^{2}$ & $0^{2 / E}$ & $\begin{array}{l}\text { Expected } \\
\text { Imeq. } \\
\text { E. }\end{array}$ & $\begin{array}{l}\text { Obs. } \\
\text { Freq. } \\
0\end{array}$ & $0^{2}$ & $0^{2 / E}$ & $\begin{array}{l}\text { Expected } \\
\text { Freq. } \\
\text { M. }\end{array}$ \\
\hline $\begin{array}{r}12 \\
8 \\
16 \\
7\end{array}$ & $\begin{array}{r}144 \\
64 \\
256 \\
49\end{array}$ & $\begin{array}{r}11.08 \\
9.14 \\
17.06 \\
6.12\end{array}$ & $\begin{array}{r}13.02 \\
6.98 \\
14.97 \\
8.02\end{array}$ & $\begin{array}{l}8 \\
6 \\
14 \\
9\end{array}$ & $\begin{array}{r}64 \\
36 \\
196 \\
81\end{array}$ & $\begin{array}{c}7.7 \\
6.34 \\
14.30 \\
8.7\end{array}$ & $\begin{array}{r}8.32 \\
5.68 \\
13.68 \\
9.32\end{array}$ \\
\hline
\end{tabular}

$x_{2}^{2}=\sum 0^{2} / E-N=43 \cdot 4-40=0.40$

at $5 \%$ level $x^{2}(.05)(1)=3.84$

$X^{2}=\sum 0^{2 / E-N=37.04-37=.04}$

Reject the hypothesis

at $5 \%$ level $X^{2}(.05)(1)=3.8$

Reject the hypothesis

Note: The $2 \times 2$ contingency table is designed to show that the two animals do not co-exist. Reject - that is, they co-exist.

In this test, the hypothesis is so that planarians and $\underline{F}$. virens do not exist together in a sampling site. The table indicates that there were two sites I, II, for repeated samples for two nonths and tho respective froquencies of occurrence of the snails and the planaria are listed in the two contingency tables IA and IB. The numbers in 
parenthesis are the expected frequencies. The null hypothesis specifies only thet each cell probability will equal the product of its respective row and colum probabilities and therefore imply independence of the two classifications. The expected frequencies would be $r_{1} c_{1} / n$ where $r_{1}$ is the ror value and $c_{1}$ is the column value and $n$ is the total nuraber of counts of planaria and snails. At $5 \%$ level of significance or even 1 io level of significance, the $\mathrm{x}^{2}$ test indicates that we do not accept the hypothesis and since there is nothing to accept, we then postulate that the planarians and snails co-exist. This might well explain why the plenarians found with the snail harbour cysts of Lissorchis and this co-existence helps in the infections because Lissorchis cercaria are inicrocercous cercarie and are poor swimmers. 
TABLE VIII

LIST OF DIDO-COMTEISAIS FROH THE FIRST INTERMEDIATE FOST - A SIAIL FIUS BNICOTA VIRENS (LRA)

CILIATES

Paramecium sp.

Euplotes sp.

Stentor sp.

Stentor $\mathrm{sp}$.

Bursaria sp.

Condylostoma $\mathrm{sp}$.

Colpidium sp.

Uronema $s p$.

Glaucome sp.

Tetrahymena $\mathrm{sp}$.

Saprophilus sp.

Monochilium sp.

ANDELIDA

Chaetogaster Iimnaei 
PABLE IX

IEASURETENT OF 13 CYSTS (DIAMETER)

$$
\begin{aligned}
& 85(84-86) \\
& 88(87-89) \\
& 87(86-88) \\
& 105(104-106) \\
& 116(915-117) \\
& 118(117-119) \\
& 99(98-100) \\
& 107(106-108) \\
& 125(123-126) \\
& 114(113-115) \\
& 117(116-118) \\
& 99(98-100) \\
& 115(114-116)
\end{aligned}
$$




\section{PNBLE X}

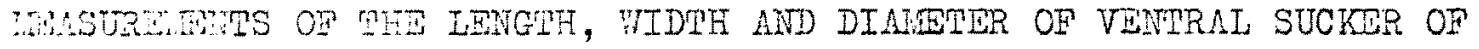
DETILOPING IISSORCTIS HANYRORCHIS

ist reek

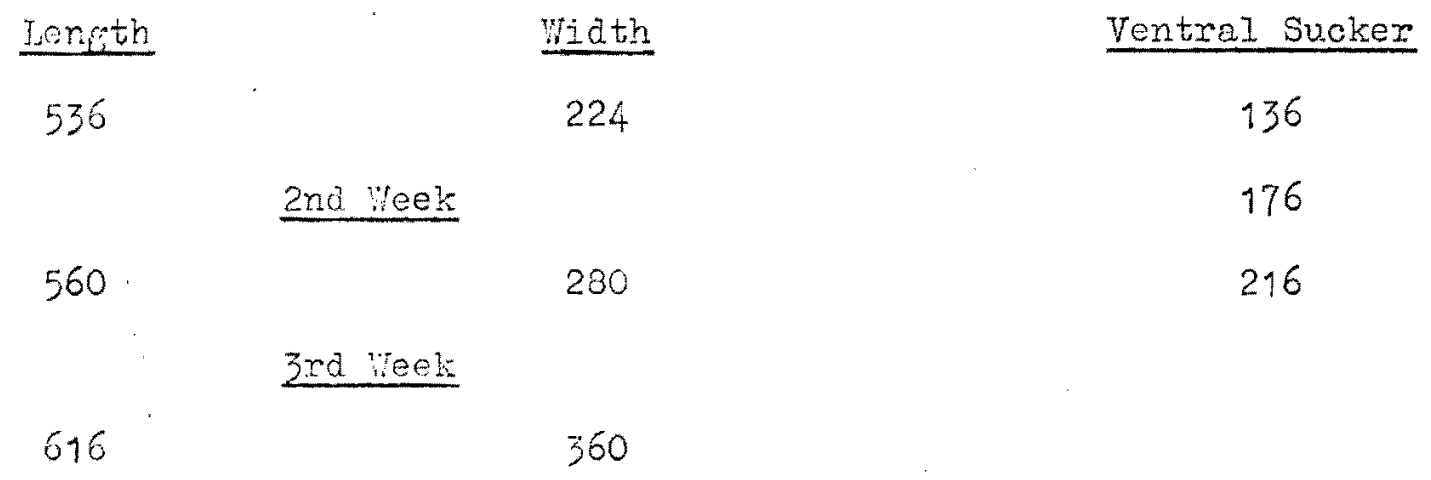


usine phase contrast microscopy and high power magnification. The keyed organisns are tabulated as shown in Table VIII. Planarians, Dragesia dorctocephala (Woodworth) exposed to infection were found to be infected almost imediately by the cercariae obtaining a grip on the surface of the nost by the oral sucker and worming its may through the surface epithelium into the mesenchyme and onwards to the pharyngeal region where the copcaria encysts as the metacercaria. Infection also was found to occur by the active ingestion of the cercaria which penetrates the out wall into the mesenchyme and encysts on the pharyngeal wall. Infection continues until the external wall of the pharynx is fully covered with cysts further encystment occurs anywhere in the mesenchyme. Encystmont is corpleted in forty-eight hours.

Exarination of the cross sections of the infected planarians under high power magnification shors that the metacercaria rolls up into a ball crter a thin cyst wall surrounds the metacercsia. Sections of infocton corcaria indicate that there is a space between the encysted corcaria ard the thin cyst wall probably secreted by the host. Sections were made after seven weels after infection.

The experimentally infected fish was opened after four weeks of serial, veekly infection. The first infection was done on the 15 th of octobor, 1971.

The results obtained from the serial infection of the definitive host is interesting. No adult was obtained with eges in the uterus. Whe three reek old adults had all the full components of the reproductive organs but no eges in the uterus. The testes were tanden and in the posterior third of the organisn. The anterior testes is clearly lobed which is diagnostic of the species whose life cycle is being 
investigated. The ovary is anterior to the testes and the genital pore lics lateral to the ventral sucker. Measurements of the longth and ridth of the entire developing parasites and the vontral suckers were taken and the Iigures tabulated as shown in Table $\mathrm{x}$.

The anturior testes of adults two neeks old were only slightly lobed. Iteasurenents of the lergth and width of the organisn were also taken. The excretory bladder was thick-walled suggesting the epitheliocystide relationship of the organism. The urinary bladder at this stage was no longer S-shaped but straight.

The adult one week old worms did not show marked. lobing of the lestes but both testes were tandem and in the posterior third of the animal with the ovary anterior to the testes.

The ventral suckers of the first week and third weeks stages shored increasing reduction in size and shifting tovards the anterior third of the organism. Measurements of the ventral suckers lend support to this observation. No îlukes were recovered from the infected suckers loft in an aquarium for 4-5 weeks. Suckers infected directly with eggs and cercarjae harboured no infection.

Plumenicola virens which vere exposed to eggs recovered from adult Iissorchis heterorchis were observed to swallow the eggs. In no case were. Miracidiua observed penetrating the snail but this does not exclude the possibility of infection via the miracidiun penetrating the snail. Snails infected in this way were examined after six weeks of infection. The cercarial stage recovered from this infection were matched with the cercarial stage obtainod from natural infection on the basis of morphology and measurements, Table VIA. $\Lambda$ t-test run to compare the measurements of tho cercariae from experinental infection and natural infection with 
respect to the diameter of the oral suckers, body length, body width, Ciameter of the ventral sucker and lastly, the tail showed that at $5 \%$ lovel of significance the two cercariae were identical.

A $2 \times 2$ contingency table based on random, inciependent and repeated sampling of Crystal Springs Creek where natural infection occurs shows that both the snails and the planarians are found together. Both are intermediate hosts in the life cycle of the parasite under investigation.

On the whole, 7200 sneils examined for infection with Iissorchis neterorchis of which 216 vere found to harbour infection, indicating a $3 \%$ level of incidence. Of the 360 planarians collected in the field and examined for the presence of metacercariae of Lissorchis heterorchis showed that only ten had the metacercariae of Iissorchis heterorchis. The incidence of metacercariae in planaria was therefore $3 \%$. Infection of the snails appear to rise only slightly in the months of llay through July and begins to reach a maximum from August through November and begins to decline from November through January. The figures are tabulated in Table I. This slight fluctuation in the level of infection of the snail internediate host rather agrees with that of infection of the second intermediate host, the plenarians (Table I). Chaetogastcr limnaei, a fresh water annelid which was reported by Snith in 1968, as servine also as second intermediate were examined and in no case rere metacercariae found in the body cavity. A total of 150 vrere exanined.

The cencaria encysts in planaria where it becomes a metacercaria. When alive, the metacercaria appears motionless except for the spasmodic cytoplasmic flow. When the metacercariae were removed from the cysts by fine dissection using entomological pins or by teasing apart 
the host, they move by stretching and contracting with the oral sucker always pointing to the direction the rom is moving. The movement is sligrish.

Ixaraination of the stained, permanent mounts of the infected planerians under high power shows that the cyst wail is thin and measures on the average (6-7) thick and no other appreciable tissue roaction is visible from the host even under oil inmersion lens. jeasurements of 13 cysts shors that the diameter is (88-112) (Table X). 


\section{DISCUSSION}

The life cycle reportcd here adheres to the pattern so far established for the family Iissorchiidae in that there is a microcercous crecria produced in the first intermediate host, a snail. The discharged cercaria encysts as a metacercaria in the second intermediate host, a planarian. The life cycle of one of the representative species of the family lissorchijdee has already been described by Wallace (1939) who established that Lissorchis mutabile is a common intestinal fluke of suckers and other catostomid fishes. Wallace (1939) demonstrated that the intermediate snail hosts were Melisome trivolis (Say) and Helicoma campanulatum (Say) and that both planerian and comansal annelid Chaetogester limnaei, may serve equally well as the second intornediate host. Snith (1968) also established that fresh water limpets Laevapex uscus (Adans) and Perrissia rivularis (Say) both serve. as the natural molluscan intermediate host of $\underline{I}$. mutabile. Lissorchis heterorchis is only the second species in the group of eleven species included in the family Lissorchiidae those life cycle has been investigatod. A brief reviet of the renus Lissorchis Magath follows in form of a key to the species. The genus Iissorchis has the following characteristics: Body flattened, elongate, tapering posteriorly and of moderate size. Cuticula covered with small spines; fleshy spines around suckers. Acetabulum powerful and as large or larger than oral sucker is also vell developed. Prepharynx and oesophagus much reduced; intestinal crura not reaching posterior end. Excretory bladder S-shaped, branching anterior to testes. Genital pore marginal and sinistral, 
situated below the midile of acetabulum. Ovary messal and lobed. No seminal receptacle; Laurer's canal present. Uterus cojled and extendine from beyon? cenital pore to posterior tip of body, filled with snali thin-shelled egss. Testes large, tandem, lying in line with ovary and posterior to it. Very large seminal vesicle and well developed cirrus antcrior to proxinal enả of uterus. Vitellaria extending on either side from posterior side of acetabulum to half way betreen posterior tip and acetabalun. Vitellarial reservoir present and Mohilis' Iand large.

Key to the species of genus Lissorchis Magath, 1917:

1. Vitelline follicles 7-12 on each side. • • • . .2 Vitelline follicle 16 or more on each side. . • . 3

2. Ovary deeply trilobed, lobes completely seperated; length of body posterior to hind testes approximately equal to combined length of the three gonads. (Van Cleave and Hueller, 1932)

Ovary compact, moderately lobed but not appearing as three seperte structures; length of body posterior to hind tests lose than the length of the three gonads. L. mutabile (Cort, 1918)

3. Cuticular spines extending to posterior end of body; postacetabular region much narrowed and triangular. . . .4 Cuticular spines extending no farther than the middle of the posterior testis; postacetabular region not narrowed, posterior and more broadly rounded. • • • • • • .5

4. Cirrus armed. . . I. gullaris (Self and Campbell, 1956) Cirrus not armed. • . . I. fairporti (Nagath, 1917) 
5. Ovary overlapoing both testis, testes wider then long, body flask shaped. . . . . . I. garricki (Birer, 1929)

6. Anterior limits of vitelline field much posterior to acetabulum. . . . I. hypenteli (Fishtahl, 1942)

7. Viteline fields reaching level of acetabulum. • . 7

8. Acetabulum about trice the size of the oral sucker. L. transluscens (Simer, 1929)

9. Cuticuler spines only on the ventral body surface and not on body margins; combined width of ceca equal to one-third of body width. - . . I. crassicrurum (Haderlie, 1953)

10. Testes distinctly lobed; posterior testis about one-third longer than anterior testis. - . L. heterorchis n. sp. 11. Vitelline fields largely confined to anterior half of body; testes not confined to posterior half of body.

L. attenatum (Van Cleave and Meller, 1932)

Viteliine fields reaching posterior third of body; testes in posterior half of body. . I. polybatura (Faderlie, 1950)

It is evident from the description of the type genus and the key that the experimental adult recovered by the writer from Catostomus macrocheilus Girard is Lissorchis heterorchis because of the lobed testes. The antorior testis of the experinental adult is more distinctly lobed than the posterior testis. The holotype specimen described by Hoy and Krygier (1969) shows that the posterior testis is more distinctly lobed than the posterior testis and this may seem to contraaict the result obtained from the experimental fish. But detaifod studies on the development of the reproductive system of a fow trematode groups made by Hsu (1937), Dobrovolny (1939), Coe (1940) 
eerly yorks by Schwarze (1885), Leuckart (1889), Looss (1892), Cary (1909) and Sinitsin (1931) indicate that the reproductive organs exhibit considerable changes in form as they mature. The experimental chult has not attained full maturity since no egrs were found in the uterus and thus the gonads may still be subject to further changes in form.

Eges from adult lissorchis heterorchis were fed to uninfected snails and the cercaria coming from these infected snails were passed on to planaria, the second intermediate host. Part of the se cercaria were motched with corcaria occurring in naturally infected snails. It was the naturally occurrine cercariae that were used in running the exporinental infection of the definitive hosts. Moreover, the cercariae discharged by the experimentally infected snails from Nehalem River penetrated and encysted in Dugesia dorotocephala and measurements of tho cysts vere identical with those of encysted cercariae from the Nehalen River (Table IX). One could safely conclude therefore that both the exporimental and natural cercariae were the same. Whe experimental results obtained from studies of the rate of cercariae discharge show that there are two peaks in the rate of the cercariae discharge, one by $2 \mathrm{PH}$ and the other by 3 MI. This seem to suggost that in waters where the infected snails occur a large proportion of cercariae are released into the water at these times and perhaps the highest infection of snails occur at these times. This remark, however, wa not investigated. Macy et. al (1960) investigated the chedding time of the cercariae of Halipegus occidualis Stefford from Ifor.isoma subcronatum and found it had its peak by 3 Ail. The experinent to show the effect of continuous light and 
continuous darkness on the rate of cercariae discherge showed that continuous light inhibits the rate of discharge whereas continuous darkness increases the rate of discherge. In an experiment conducted by Why (1959) on the effect of reversed light and darkness it was found that snails kept in the dark during the day shed more than three times as many cercariae as dia those exposed to light at night. This result arrees with tho result of exposing the shedding snails to continuous licht (iorty-eight hours) and continuous darkness. It appears, therefore, that light has inhibitory effect on the rate of cercariae discharge. Any attempt at explaining this will be based on speculations and extrapolations from experiments on the photophysiological effects on some other described invertebrates. A number of possibilities exist to account for the observed inhibition of cercariae dischare: a) Direct effect of light on the nervous organs of the snail - a number of other studies have shown that many invertebrate nerve cells are light sensitive, and that although the neurones involved may be playing other roles as well, their photoreceptor properties have physiological significance in altering the chemical nature of the body fluids and bring about physical reaction to the light source. Prosser (1934) demonstrated that illumination of the sixth abdominal ganglion in craytion causes tonic increases in the spontaneous discharge of the whole ventral nerve cord. It is possible that light striking the nerves of the infected snails in a continuous manner (forty-eight hours) induces the rerves to effect some change in the body fluid of the snail and bring about some physical and chemical changes not knom, that lowers the rate of corcariac discharge. Evidences are massing up as to the effect of light in eliciting hormonal action in some invertebrates. Classical 
exannles are the light and dark adapting reactions of crustaceans, Carlisjo and ínomles (1959); action of the photoperiod in controlling incect diapause, Adkission (1964); effect of removal eyestalk on the frowth and maturation of the cocytes in hermaphrodite pra:m, Pandalus kessler soto (1956) and a host of other works. It is possible that continvous light in some way affects the hormonal action of the snail in a ray as to inhibit the shedding rate of cercaria. Cook (1970) has proved conclusively that light induces photoreaction of animal cells by attacking DIA and RNA molecules and thereby bringing about missense or nonsense mutation. The mutant gene may then synthesize abnormal protein within the body that may have inhibitory effect. This last possible explanation, however, is not plausible because mutation and oythesis of inhibitory proteins may not occur as rapidly as in fortyoirht hours.

The inhibition may be caused by the integrated effects of the nerves and the hormones, two systems that are hard to seperate. So far, no work has been done to investigate the physiological causes of the drop in tho rate of corcariae discharge from the report given by Macy (1959). Such an invostifition may throw some light on phsyiological response of the infocted snails to the effects of continuous light, reversing light and larkness or continuous darkness. It was found also that the rate of shedding increases with time and reaches a plateau in wich there is no moro discharge. The rete of cercarial discharges average ten per hour as compared with 200 per hour reported for Plaxiorchis vespertilionis marolis incy, 1959. This result indicates a low level of cercarial productivity. This might partially explain the low level of incidence of jufoction aroong the second intermediate host - and, hence, the Iow 
level of infoction among the definitive host. Out of a total of 150 nuckors oxanined, only five (only $3 \%$ ) had infection. It is interesting to point out that there is a $3 \%$ level of incidence anong the snails, the intermediete host and the definitive host. This presupposes a stcady state of inrection. This level of infection varies slightly fron zeason to season.

Ecoloyical studies carried out at Crystal Springs Creek revealed that at certain spots at the botton of the creek where Ilumenicola virens occur, brom and wite plenarians also are found under rocks and peboles. Ind, at one tine, a young sucker was caught in a dip net where the snails and planarians occur. Examination of some of the snails and planarians show that some of the snails had Jissorchid cercariae and some of the plenarians harbored cysts which, on closer examination and measurements, ntched with the experimental cysts of Lissorchis. A $2 \times 2$ contingency test basco on repeated sampling for snails and planarians for two months showed that the two animals are not mutually exclusive. It seems, therefore, that in nature the set up for the life cycle of Lissorchis haterorchis is vell constructed in that the definitive host, a sucker Catostomus macrocheilus Girard, is at hand to release egrs of the trematode, Iissorchis heterorchis which is either directiy swallowed by the snail Flumenicola virens during feeding or by the active penetration of the snail by the miracidium. Within the snail rediae are devcloped. The rediae give rise to microcercous cercarice which are shed in small amounts into the surrounding waters. The cercariae easily ind tho planarians into which they penetrate and encyst close to the wharynx es metacercariae. Suckers which are omivorous and benthic feed upon infected plenarians from the rocks. The metacercariae are 
reloasod into the intestines, of the suckers by the digestive enzymes, where the adult mature in the midgut or posterior intestine.

A close examination of sections of infected planaria show that there is very litule host reaction. The cyst wall formed is very thin. This lack of host reaction indicates that the host is very rell adapted to the perasite and would suggest a long tire evolutionary relationship.

Several other snails such as oxytrema silicula (Gould) which are Cound in the sane habitat as Flumenicole virens were examined and in no case was a lissorchid cercariae found. It is likely, therefore, that the liscorchid cercariae were limited to only Elumenicola virens as first intermediate host. This would indicate that the cercariae of Isserchis hetorocchis exhibits strict host specificity.

M interesting feature of this life cycle studies is the fact that two intermediate hosts, first a fresh water snail and second, a planarian, a free living flatworm are involved. Earlier work by Smith (1968) on the life cycle of Iissorchis mutabile shows that this species could also use ancylici snails as first internediate host instead of an operculate freshwater snail. It may be portinent to point out that in this life cycle as also reported by fallace (1939) on the life cycle of I. mutebile, a parasitic flatworm has reverted to using a free living flatworm in the completion of its life cycle. This phenomenon suggests a physiological compromise between the free living and the parasitic flatworms. Penetration into the free living flatworm is facilitated by the possession of the ponetration flands by the parasitic flatworm and by its wormlike movement into the body of the free living flatworm. Encystment in the cecond intormediate host is assisted primarily by the favorable host roaction. It is the physical presence of the worn and the chemical 
aubstance secreted by a parasite that elicit the formation of a cyst wall around the parasite within the host. These points are of interest in the problem of host spocificity. The use of ancylid snails other than a pulmonate snail by lissorchis mutabile in its lifo cycle is inturesting since in trematode families and superfamilies thore is a rieidity for intramolluscan generations compared to other stages in the life cycle.

Evidence coming fron this investigation shows that the definitive host doos not pick up infection either by swallowing the eas or the cercaria directly. Also, the cercariae within the second intermediate host has to bo within tie planaria for at least five weeks to be infective. Snith (1968) working on the life cycle of Iissorchis mutabile states that the cercaria has to be encysted in the second intermediate host for at least seven weeks. This difference in the infectivity of the encysted cercaria with rospect to the time period within the second intermodiate host may be due to the diference in species. After the derinitive host has been infected, Vallace (1939) reports that the longevity of the parasite vithin the definitive host was three weeks. Por Ijissorchis heterorchis it was found between four and five reeks. For such short time periods within the definitive host, it is necessary for the definitive host to be constantly reinfected by eating the second intprmoiate host. In order to maintain this life cycle, Nagath (1917) claim that the bufialo fish frys, the definitive host for Lissorchis mutabile feed profusely on the second intermediate host. It is likely that tho suckers also feed profusely on planarians to maintain infection ospocially at the level of infection among the planarians is low. 
The problem of taxonomic confusion within the Eroup to which Lissorchis heterorchis belong is expressed: "Mlthough synornyizing Prignodiitomura with Lissorchis is required by present knowledge of species heretoforo assigned to these genera, the systematic position of the group, remains uncertain," Smith (1968). This statenent currently is hot true, for the eleven described species which were split under the genera minamodistomum and Iissorchis have been assigned to a single yenus Lissorchis under the family Iissorchilidae and so for now the taxononic confusion has been cleared. This was at least cleared by lacy and Krygir (1969) after their discovery of the eleventh species, Lissorchis heterozchis, with a key to the species attached and up till the time this paper is being written, no new species review has been published. 
Adkisson, P. I. 1964, Action of the photoperiod in controlling insect diapase. An. Nat. 98:357-374.

Lotu, T. and Mishida, H. 1956. Effects of removal of eyestalk on the frowth and neturation of the oocytes in a hermaphroditic pravm, Pentelas kessleri. F. Fac. Sco., Itokkaido Univ., Ser. 6 Zool. $12: 412-124$.

Bongham, R. V. and Alams, F. R. 1954. A survey of the parasites of freshruter fishes from the mainland of British Columbia. J. Fish Res. Bd. Conada. 11:673-708.

Caballero, Y. C. 1942. Trematodes de los Murcielogos de Wexico Iv. Description de un nuero de la subfanilia Lecithodendrinae Looss, 1902 y ur nuero especia de Prosthodendrium Dollfus. 1931. An. Inst. Biol. Hex. 14:173-193.

Carlislo, D. B. and Knowles, R. 1959. Endocrine Control in Cmastaceans. Cambridge University Press.

Coe, \%. R. 1940. Divergent pathmays in sexual developnent. Science, $91: 175-182$

Cook, S. I. 1970. Photoreaction of Animal Cell - Photophysiolory. Academic Press, Tiew York and London.

Cort,.$\because$. 1913. A Mow Cercariaeum from North America. J. Parasit. $5: 36-91$

Dobrovolny, C. G. 1939a. The Life History of Plagioporous lepomis,

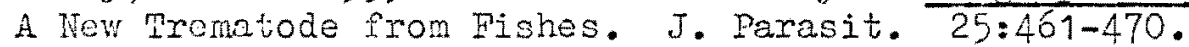

Dobrovolny, C. G. 1939. Iife Cycle of Plafioporous sinitsini Mueller and Bmbryology of $\mathrm{New}$ Cotylocercous cercariae (mrematoda). Trans. Amor. Nicro. Soc. 58: $121-155$.

Ercolani. 1891. Dell addatamento della specie all ambiente. Nouve recerche sulla storia genetica dei Trematodi. Mer. Acad. Sci. Inst. Bologna. Ser. IV. 2:239-334.

Faust, 3. C. 1930. Cercariaeum sinense spn. in Bithynia fuchsians. J. Parasit. 22:154.

de Filippi. 1859. Troisieme memoire pour servir a phisorie geretique dos trematodes. Hem. Acad. Sci. Tousin Ser. 18:201-232.

Hisu, J. Y. 1937. The life history and morphology of hacravestibulum eversum sp. nov. Pronocephaliidae, Trematoda. Trans. Amer. Kíler. Soc. $56: 478-504$.

Fussey, K. L. 1939. Development of the excretory system in digenetic trematodes. J. Parasit. 25:9. 
Koboyani, F. 1922. A Roview of Japanese Cercariae. Ititt. d. med. Aked. a kijo. po. 1-27.

Krygier, B. B. and R. W. Wecy. 1969. Ijssorchis heterorchis sp. n. (Promatoda: Lissorchiidae) from Catostomus mecrocheilus Girard in Orcson. Proc. Helm. Soc. Wesh. 36:136-139.

Leuckart, R. 1039. Die Parasiten des Menschen und die von ihnen herruhrenden Krankheiten. Ein Handund lehrbuch fur Naturforscher und Aerzte 2 Aufl. VI Lief, 2, Abt. 9:97-440.

Li, J. C. R. 1064. Statistical Inference. Edwaras Bros., Ann Arbor, Mich.

Looss, A. 1822. Veber Arnphisotormm subclavatum Rud. und seine Trtivickling rests. zum 70 Geburts R. Leuckarts. Seite 147 bis 167 Leipitz.

Luhe, 19. 1909. Parasitische Plattmurmer, I. Trematodes. Susswasserfeuna Deutschlands Heft. 17:217.

Mroy, R. 1. 1960. The Life Cycle of Plegiorchis perorchis n. sp. (Trematoda: Plagiorchiidae). J. Parasit. 42:28.

Nivgath, T. 3. 1917. The Morphology and Life Cycle of a New Trematode Parasite Iissorchis fairporti Nov. Gen., et Nov. Spec. from the Buffelo Fish. Iotiobus J. Parasit. 4:58-69.

Michllon, D. B. 1937. The Life Histories of Three Trematodes Parasitic In Birds and Mammals Belonging to the Genus Plamioris. J. Parasit. $23: 235-243$.

Petors, I. and J. T. Self. 1963. An Allocreadiid cercaria from Limpets (Mbstr.). J. Parasit. 49:41.

Petersen, H. 1931. Cercarien der Miederelbe. Zool. Anz. 97:13-27.

Prosser, C. I. 1934. Spontaneous impulse in crawfish ganglia. J. cell and Comp. Physiol. 4:185-209.

Prosser, C. L. 1935. Impulses in segmental nerve or earthworm. Exp. Biol. 12:95-104.

Prosser, C. L. 1934. Nerrous mechanisms in reactions of earthrorm to licht. guart. Rev. Biol. 9:181-200.

Seve11, R. B. 1922. Cerceriae Indicae. Indian I. Med. Res. 10:1-370.

Sinom, P. H. 1929. Fish trematodes from the lower Tallahatchie River. Aner. Nidl. Nat. 11:563-588. 
Sinitsin, D. T. 1911. Te cencration parthe no geneteque des trematodes ct sa descendance dans les mollusques de la Her Noire. Jiem. Acad. Sci. St. Potersbours. (Revised translation of tho Russian text edited by G. R. Iarue, 1925.) 30:1-127.

Snith, R. J. 1967. Ancylid snails and intermediate hosts of 10galodiscus tenperatus and othon digenetic trematodes. J. Parasit. 53:287-291.

Stafford, J. 190/. Trematodes from Canedian Pishes. Zool. Anz. $27: 481-496$.

Stunkird, $\because$. I. 1934. The Iife History of Typhlocoelum cymbium (Diesinz, 1050), Kossack, 1911 (Trematoda, Cyclocoelida). A contribution to the phylogeny of the monostomes. Bull. Soc. Zool. de France. $59: 47-466$.

Van Clozve, H. J. and wucller, J. F. 1934. parasites of Oneida Iake Fishes. Roosevelt Wild Life Bull. 3(3,4):155-373.

Wallace, 7. B. 1939e. Development of the Bxcretory System in Cexcarineun mutabile (Cort): Trematoda. J. Parasit. 25:27.

Wallace, Y. E. 1939. Lîe History of Prigansdistomum mutabile (Cort): Trematoda. J. Parasit. 25:26-27. Life History and Embrylogy of Trimanodistomum mutabile (Cort) (Hissorchiidae, Trematoda). Ir. Am. incro. Soc. 1941 . pp. 60 . 
PL. (1.1) X4200 the cercuria of Lissorchis heterorchis showing the rlame cell pattern.2[(2+2+2+2)+(2+2+2+2)] a.) excretory tubule; b.) flame cell cell; f.) excretory bladaer (Left side of flame cells is onitted.)

II. (1.2) X200 Rodia showing contained cercariae. c.) dark pigment; ß.) cercaria

PI. (1.3) X1500 The cercaria of Iissorchis heterorohis. d.) the gut; e.) the spined tail

P1. (2.1) K1400 The cercaria of Lissorchis heterorchis. 4,5 germ cell primorida - testes and ovary; 6 , the penetration glands. The penetration glands are six on either side.

PI. (2.2) $x 2800$ Cross section of the infected planaria Thasesia dorotocephala. 3, cyst

21.3 Developmental stages rithin the definitive host of Lissorchis heterorchis. $3 \cdot 1$, two-dey stage shoming a single ovary just above testes that are semi-tandem. $3 \cdot 2$, one reek stage in which the testes lie well below the ovary and testes are quite tandem. The anterior testis shows a little lobing. $3 \cdot 3$, second week in which the anterior testis is clearly lobed. 3.4 , third week stage in which the posterior ovary shows signs of lobing. $3 \cdot 5$, posterior of $3 \cdot 4$ enlarged.

21. 4 The dorsal view of a fully developed Iissorchis heterorchis hacy and Krygier (1969) (Drawn by the courtesy of nacy, R. W.). 
P1. 5

P1. 6

PI. 7

11. 8

21. 9
Life cycle pattern of Lissorchis heterorchis. Drawing of altemative second intermediate host Chactogaster limaei. $6 \cdot 1$, posterior of the orgenism showing arrangement of bifurcate spines. $6 \cdot 2$, an enlarged draving of a spine. $6 \cdot 3$, anterior end of the worm. $6 \cdot 5$, the pharynx. $6 \cdot 6$, the mouth. Scele: $1^{\prime \prime}=1$ unit in $X$ axis and 10 units in $Y$ axis. Hourly number of cercariae shed at night with a peak by 2 PN.

Scale: $1^{\prime \prime}=1$ unit in $X$-axis and 10 units in $Y$ axis. Daylight number of cercariac shed in 15 hours with peaks between 12 noon to 3 PII. Scale: $1 "=1$ unit on $X$-axis and 10 units of $Y$ axis shows the cumulative number of cercaria shed in 16 hours. 


\section{ADDENDUTH}

Fepuration and formula of dyes and solutions used in this investigation. Farris' Alum Hematoxylin

Do:1. ths hematoxylin and ammorium alum together in the distilled vater and add mercuric oxide. Prepare the stain at least one weok before use. The solution will keep for a considerable time and may be reduced. If a scun"develops on the solution it should be filtered.

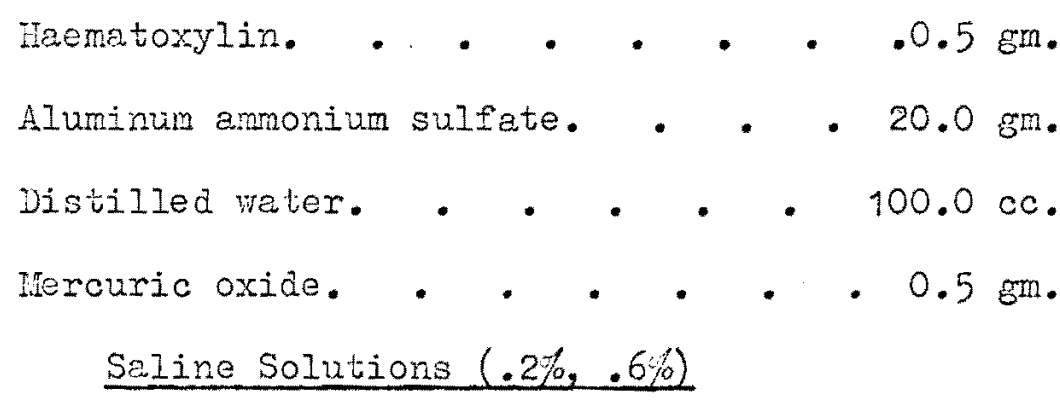

Woin out the appropriate veight of the sodium chloride and dissolve in $100 \mathrm{cc}$. of water. (.2\% saline)

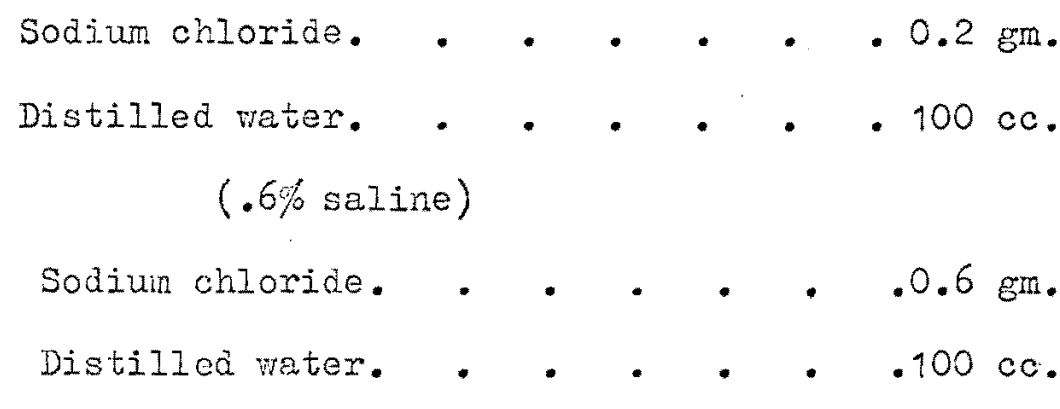

Bouins Fluid

Picric acid (saturated aqueous solution). $75 \mathrm{cc}$ Pornelin. . . . . . . . . $25 \mathrm{cc}$. Glacial acetic acid. - . . . . $5 \mathrm{cc}$. 